\title{
Immunostimulants for shrimp aquaculture: paving pathway towards shrimp sustainability
}

\author{
Santosh Kumar ${ }^{1} \cdot$ Arunima Kumar Verma $^{2} \cdot$ Shivesh Pratap Singh ${ }^{2} \cdot$ Abhishek Awasthi $^{3}$
}

Received: 1 October 2021 / Accepted: 27 December 2021 / Published online: 13 January 2022

( $)$ The Author(s), under exclusive licence to Springer-Verlag GmbH Germany, part of Springer Nature 2022

\begin{abstract}
At present, food security is a matter of debate of global magnitude and fulfilling the feeding requirement of $>8$ billion human populations by 2030 is one of the major concerns of the globe. Aquaculture plays a significant role to meet the global food requirement. Shrimp species such as Litopenaeus vannamei, Penaeus monodon, and Macrobrachium rosenbergii are among the most popular food commodities worldwide. As per Global Outlook for Aquaculture Leadership survey, disease outbreaks have been a matter of concern from the past many decades regarding the shrimp aquaculture production. Among the past disease outbreaks, white spot disease caused by the white spot syndrome virus is considered to be one of the most devastating ones that caused colossal losses to the shrimp industry. Since the virus is highly contagious, it spreads gregariously among the shrimp population; hence, practicing proper sanitization practices is crucial in order to have disease-free shrimps. Additionally, in order to control the disease, antibiotics were used that further leads to bioaccumulation and biomagnification of antibiotics in several food webs. The bioaccumulation of the toxic residues in the food webs further adversely affected human too. Recently, immunostimulants/antivirals were used as an alternative to antibiotics. They were found to enhance the immune system of shrimps in eco-friendly manner. In context to this, the present paper presents a critical review on the immunostimulants available from plants, animals, and chemicals against WSSV in shrimps. Looking into this scenario, maintaining proper sanitation procedures in conjunction with the employment of immunostimulants may be a viable approach for preserving shrimp aquaculture across the globe.
\end{abstract}

Keywords Shrimp sustainable aquaculture $\cdot$ White spot disease $\cdot$ White spot syndrome virus · Food security $\cdot$ Eco-friendly Immunostimulants $\cdot$ Antivirals

\section{Introduction}

One of the most pronounced provocation of the future is to fulfill the feeding requirement of $>8$ billion human population by 2030 (Ferri 2010). With the mission to achieve

Communicated by Philippe Garrigues.

Responsible Editor: Philippe Garigues

Abhishek Awasthi

drabhishekawasthi28@gmail.com

1 Department of Zoology, Maharaja Agrasen University, Baddi, Solan, Himachal Pradesh, India

2 Department of Zoology, Government Autonomous P.G. College, Madhya Pradesh, Satna, India

3 Department of Biotechnology, Maharaja Agrasen University, Baddi, Solan, Himachal Pradesh, India sustainable future for all the mankind on the earth, the United Nations (UN) General Assembly had proposed Sustainable Development Goals (SDGs) that are intended to be achieved by year 2030 under the UN resolution called the Agenda2030 (Ferri 2010). The Goal2 of the SDGs is to accomplish "Zero Hunger" across the globe by 2030. It aims to end hunger, attain food security and nutrition, and endorse sustainable agriculture worldwide. As per the official website of GOAL2, currently, almost $8.9 \%$ of the world population is hungry and the population would escalate up to 10 million people in 1 year/60 million people in 5 years. As per the World Food Programme, almost 135 million global population is suffering from acute hunger principally because of anthropogenic clashes, climate change, and economic deflation. Looking into such a scenario, an intense revolution of the global food and agriculture systems is required that can promote agricultural productivity and sustainable food production so as to accomplish the hunger demands globally. 
Fishes and other aquatic foods play a pivotal role to achieve nutrition and food security goals (Béné et al. 2015; Thilsted et al. 2016; Willett et al. 2019). Aquaculture is also being considered to be one of the most promising foodproducing sectors with the largest potential to accomplish growing demand of food (Das et al. 2017). If the chronological trends related to income and population growth, urbanization, and diets remain conserved, then demand for seafood will increase extensively over the years (2030-2050) (Willett et al. 2019). Furthermore, seafood are claimed to evidently provide more environmentally sustainable animalsource foods (Hallström et al. 2019). Crustaceans serve as an important aquatic food commodity, and among the crustaceans, the shrimps constitute the most significant group that contribute to the global fishery sector (Bondad-Reantaso et al. 2012). Shrimp and prawns have been recognized as most heavily traded fish products. Asia and Latin America have lion's share in bulk production of shrimps while USA, the European Union, and Japan are the major consumers of shrimps.

The Global Aquaculture Alliance's GOAL (Global Outlook for Aquaculture Leadership) 2019 survey depicted global shrimp aquaculture production with reference to different regions in the part of the world over a decade from 2010 to 2021 (Fig. 1). Figure 1 summarizes estimated global production of shrimps and reported a surge in shrimp production in 2018 which would further escalate through 2021. As per businesswire.com, the global shrimp market faced deterioration due to COVID-19 lockdown but still it was enumerated to be US $\$ 18.30$ billion in 2020 and is expected to be US\$23.4 billion by 2026 .

From past few years GOAL surveys, some of the most stimulating challenges faced by Asian shrimp market were reported to be as follows: (i) disease outbreaks, (ii) feed costs, (iii) access to disease-free brood stock, (iv) international market prices, disease outbreaks being the most important cause for the hampered shrimp production and trade. The most popular shrimp species consumed worldwide are Litopenaeus vannamei, Penaeus monodon, and Macrobrachium rosenbergii. Lessons from the past show that the global shrimp market has suffered adversely due to the impact of disease outbreaks (FAO 2020). Among these outbreaks, white spot disease (WSD) is one of the most devastating diseases caused by white spot syndrome virus (WSSV) that has severely affected the shrimp crops from the past many decades. Here, we review the most common approaches to deal with WSD and enumerate the disease mitigation process for WSD with special reference to immunostimulants.

\section{White spot disease in shrimps}

White spot disease (WSD) is one of the most devastating viral diseases caused by white spot syndrome virus (WSSV) (Chou Hsin-Yiu et al. 1995; Nadala and Loh 1998; Rajan et al. 2000; Pradeep et al. 2012). Till date, almost 98 probable host species have been recognized

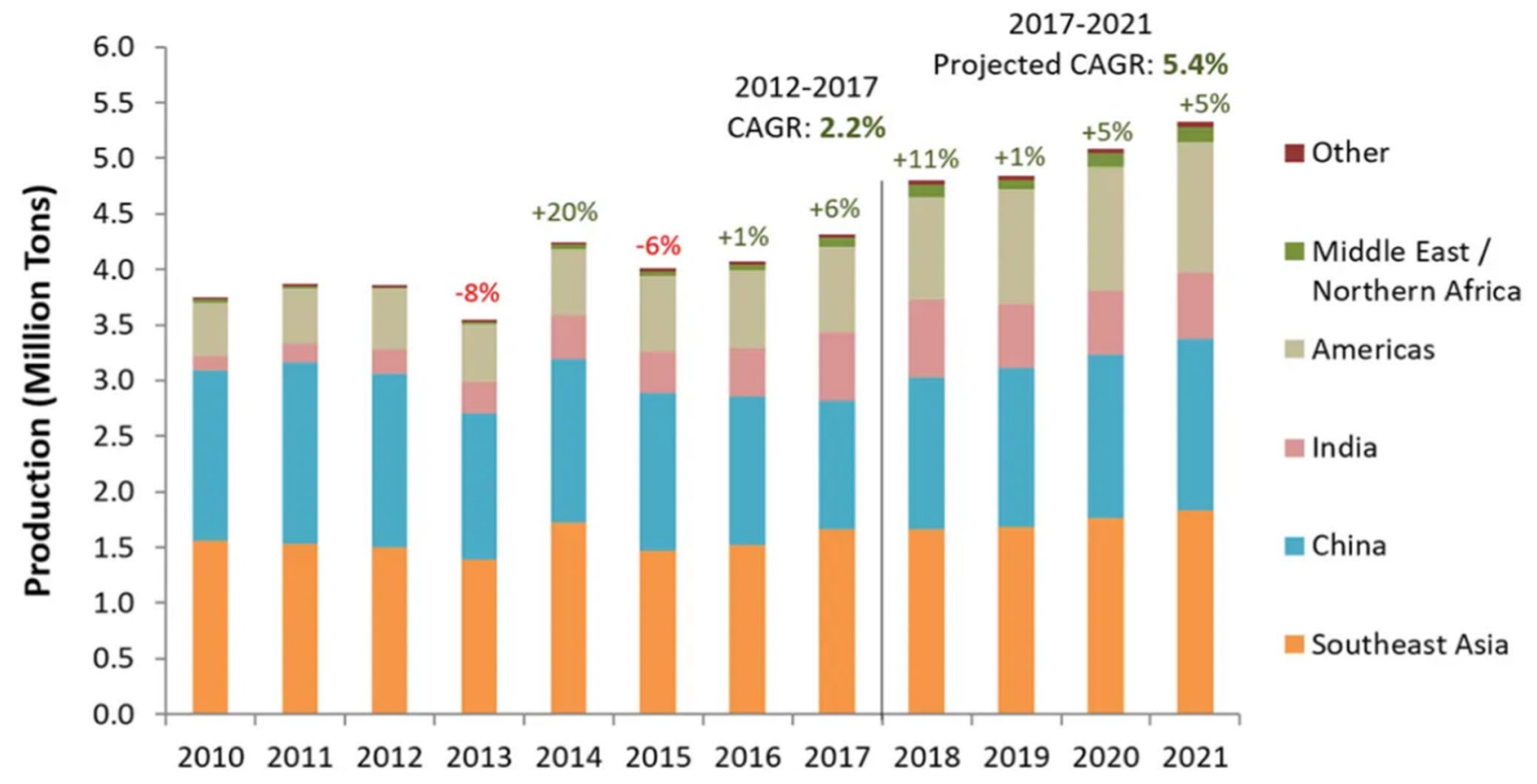

Fig. 1 Shrimp farming production by region. Courtesy-Global Seafood Alliance 
and documented for WSD (Stentiford et al. 2009). From the past several decades, the prime focus of researchers was on WSD caused largely in farmed shrimps (such as Penaeus monodon, Fenneropenaeus indicus, Marsupenaeus japonicus, Litopenaeus vannamei, Penaeus merguiensis, Penaeus indicus, Penaeus chinensis, Penaeus duorarum, Penaeus vannamei, Penaeus japonicus, Litopenaeus setiferus, Macrobrachium rosenbergii). The disease can annihilate entire shrimp population within 3-7 days of its commencement.

At present, an absolute treatment in form of drug etc. is unavailable for WSD. The major cause behind unavailability of any effectual treatment is due to multifarious reasons, and some are (i) paucity of properly sequenced and annotated host genome sequences, (ii) lack of complete information on the functional aspects of pathogenesis (such as ingression/penetration of virus into the host, its dissemination/propagation within the host body) of WSSV, (iii) lack of in-depth understanding of host-pathogen molecular interactions at the protein level, and (iv) presence of innate immunity in the shrimps. Despite the fundamental knowledge gaps in this line, major efforts have been made to review the entire disease mechanism especially during entry and propagation of virus in the shrimps (Verma et al. 2017) and further progression of the disease in the host body (Verbruggen et al. 2016) at the molecular level.

\section{Immune system of shrimps}

The innate immune system of shrimps embodies profuse natural defense mechanisms, and few to name are (i) a microbial recognition system, (ii) a prophenoloxidase cascade system (proPO system), (iii) a coagulation system, (iv) phagocytosis, (v) encapsulation, (vi) formation of nodules and reactive oxygen compounds, and (vii) hemocyte mobilization (Stentiford et al. 2009; Johansson and Soderhall 1989) (Fig. 2). The microbial recognition system is mediated by the pattern recognition proteins (PRPs) (Medzhitov and Janeway 1997; Janewey and Medzhitov 2000), which catalyzes the primary tread for automatically identifying the non-self material that has intruded into the host body. The PRPs have an intrinsic ability to spot out the conserved molecules located on the exterior facet of infringing microorganisms. Such conserved domains/patterns are called as pathogen-associated molecular patterns (PAMPs) such as lipopolysaccharide (LPS) and peptidoglycan (PG) from bacteria and laminarin from fungi (Janeway 1989). As soon as the PRPs get associated with PAMPs, a cascade of immune responses gets initiated which further stimulates the host-defense system. C-type lectin is one of the most important examples of PRPs in the invertebrates, which play crucial role in shrimps while fighting against various viral and bacterial diseases. The immune system of shrimp is inseparably associated with its hemolymph and hemocytes that implicate to the cellular defense mechanisms, viz., phagocytosis of the pathogens,
Fig. 2 Immune system of shrimps

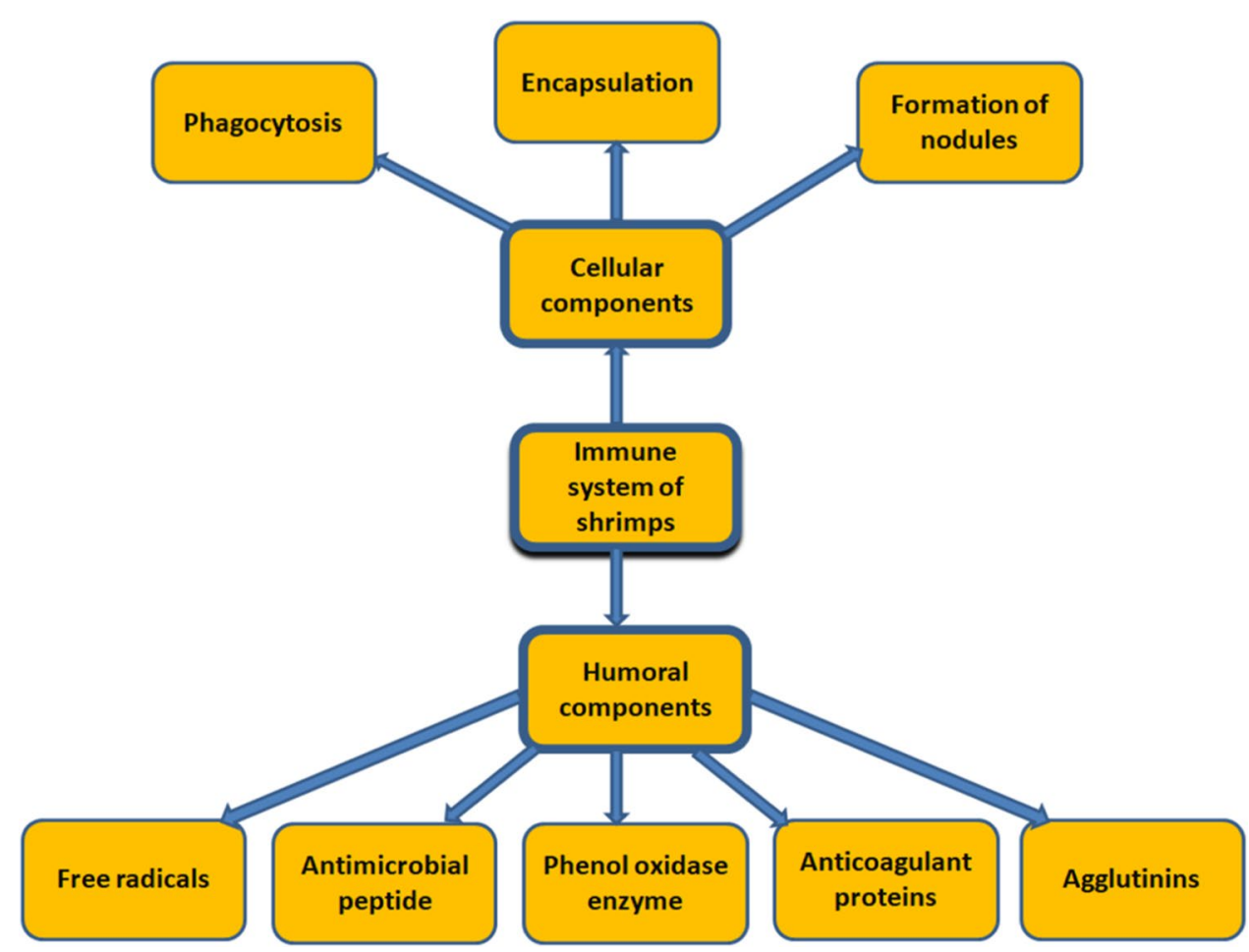


and encapsulation as well as breakdown of foreign material (Liu et al. 2007). Furthermore, the hemocytes also play an imperative role in the cellular immune response including encapsulation, clotting, non-self-recognition, melanization, phagocytosis, cytotoxicity, and cell-to-cell communication (Söderhäll et al. 1998).

In crustaceans, when any foreign material (bacteria, virus, or any other pathogen) invades the host organism, then a cascade of cellular defense reactions are initiated that finally activate melanization process in host body (Hirono et al. 2011). PO, the chief enzyme responsible for the production of melanin, occurs in hemolymph of host in the form inactive proPO. ProPO gets activated to form PO on reacting with zymosan (carbohydrates from yeast cell walls), bacterial lipopolysaccharide (LPS), trypsin, calcium ions, urea, or even heat that eventually triggers melanization in the host. Along with triggering melanization process, the proPO system also activates defense mechanisms, involving encapsulation, nodule formation, phagocytosis, and hemocyte locomotion (Johansson and Soderhall 1989). Stimulated hemocytes in turn make extra bactericidal substances, such as $\mathrm{H}_{2} \mathrm{O}_{2}$ and superoxide anion $\left(\mathrm{O}_{2-}\right)$ that boost host disease resistance (Johansson and Soderhall 1989).

\section{Disease mitigation strategies used for shrimp aquaculture}

The disease mitigation strategies employed in order to prevent shrimp disease include antibiotics/chemotherapeutics, vaccination, and immunostimulants (Apines-Amar and Amar 2015). Asia Pacific is accounted to be the largest fish producer as well as exporter in the aquaculture market. Such countries always remain under a stimulated pressure of producing high-quality aquaculture products. In order to attain this objective, efficient aquaculture operations and technology adoption work in amalgamation with automation to deliver the best quality-assured aquaculture harvest. Moreover, some shrimp species are very receptive to variety of bacterial, fungal, and viral diseases. In such scenario, the fish farmers or feed manufacturers started using "antibiotics" as a preventive and therapeutic measure. The practice of using antibiotics in recent times has become customary to cure the recurrent diseases occurring in the aquatic species.

The repercussion of using antibiotics in aquaculture is that it adversely affects aquatic micro-flora, leading to accumulation of harmful residues in the aquatic organism, and also develops drug-resistant bacteria and pathogens (Singer et al. 2019). Such antimicrobial resistant bacteria/ pathogens are usually transferred from fish to humans via the food chain. Thus, in general, the human may acquire antibiotic-resistant bacteria that can eventually lead to adverse drug reactions and cause treatment resistant illness or even mortality (Fig. 3). In the modern era, a lot of awareness is being laid on the food safety for good health and well being. Thus, use of antibiotics is often forbidden in the aquaculture systems. In fact, the Marine Products Export Development Authority (MPEDA) of India has enumerated a list of 20 antibiotics that are debarred for their usage in the aquaculture. Some of them are chloramphenicol, nitrofurans, neomycin, nalidixic acid, chloroform, colchicine, ronidazole, ipronidazole, sulfonamide drugs, fluroquinolones, glycopeptides, etc. The biomagnifications and bioaccumulation of antibiotics in the food chains and food webs caused huge repercussions. Increasing antibiotic resistance among aquatic bacteria has been documented in several studies (Rhodes et al. 2000; Miranda and Zemelman 2002) and others, all of which used antibiotics as prophylactics during the rearing of shrimps and salmon in water bodies (Grave et al. 1999). In addition, antibiotic resistance in shrimp and fish pathogens has increased over the years (Rhodes et al. 2000). Antibiotic residues were accumulated in aquaculture products owing to the aggravated usage of antibiotics (Grave et al. 1999; Cabello 2006; Aguirre-Guzmán et al. 2010). That in turn leads to an increased accumulation of antibiotics in the consumers of aquatic commodities (Grave et al. 1999; Salyers et al. 2004). Consequently, there is a risk of antibiotic-resistant bacteria spreading from aquatic to terrestrial and human sources (Miranda and Zemelman 2002; Cabello 2006). Antibiotics in food may also create allergic reactions and toxicity issues that are difficult to assess because of a lack of prior knowledge on antibiotic intake in the food supply (Cabello 2006). Antibiotics may cause a wide range of allergic reactions and toxicity issues in aquaculture employees who are not properly safeguarded from them. It is possible to develop an allergy or toxicity to antibiotics when employees provide antibiotics to fish

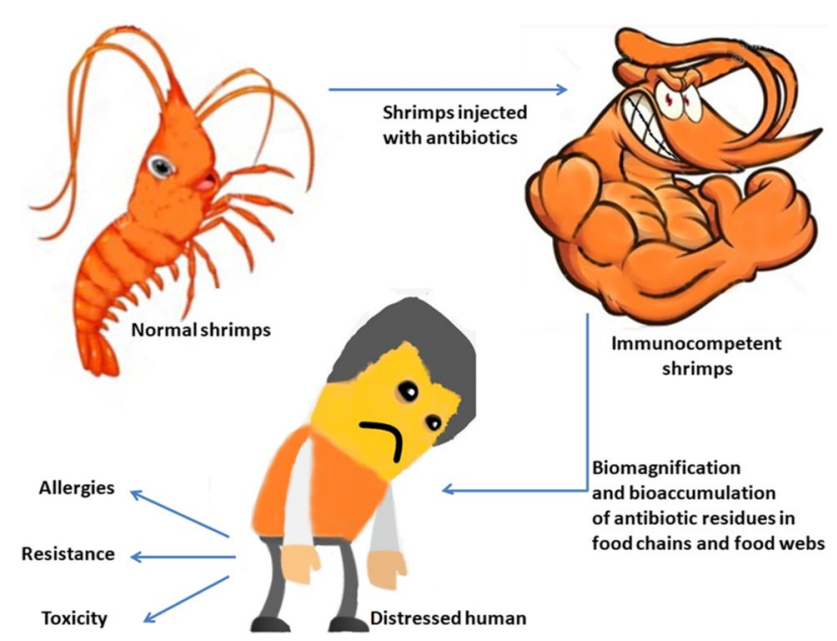

Fig. 3 Effects on antibiotics on shrimp aquaculture and environment 
or shrimp by touching their skin or ingesting significant quantities of antibiotic-treated food (Grave et al. 1999; Cabello 2006). It in turn paves path for employment of probiotics and natural medicines in the aquaculture to sustain optimal food safety and human health.

Vaccines and immunostimulants are prophylactic in nature and are used to make the host immune-competent. Musthaq and Kwang examined in detail the prospects of vaccinations for WSD (Syed Musthaq et al. 2009). A concept of pathogen-specific "immune priming" has been cited in recent studies and is considered to provide an optimized solution in vaccine efficacy against WSD (Yang et al. 2021). It involves application of viral RNA/DNA, attenuated viruses, and recombinant viral proteins. The major drawback with all these treatments is that it provides temporal protection (Verbruggen et al. 2016). Hence, vaccination serves to be a promising means to fight against diseases but there are not much effective vaccines against most shrimp viruses (Fig. 4). Unlike mammals and other vertebrates, shrimps do not possess adaptive immune system and therefore have to depend on the innate immune system. Therefore, developing vaccines for shrimps is quite cumbersome and subject of ongoing investigations. In addition, they are very costly and vaccinating each and every shrimp individually is a tedious job.

Thus, at present, the immunostimulants depict the most innovative approach in order to fight the shrimp diseases (Barman and Nen 2013). Immunostimulants are molecules that effectually boost non-specific defense machinery of the host to combat against invading microorganism. They compensate the discrepancies of chemotherapeutant/vaccine usage and provide a moderate solution in regard to the shrimp immunity. Hence, immunostimulants might be considered a prospective option for shrimp health management (Fig. 5).

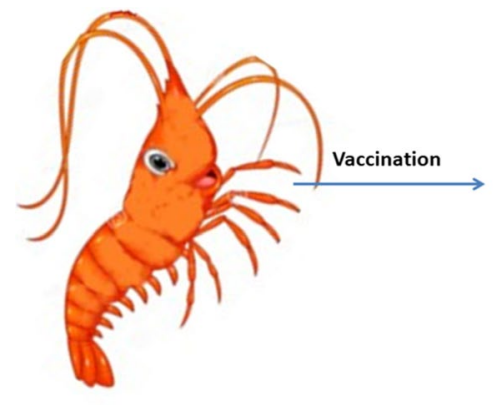

Normal Shrimp

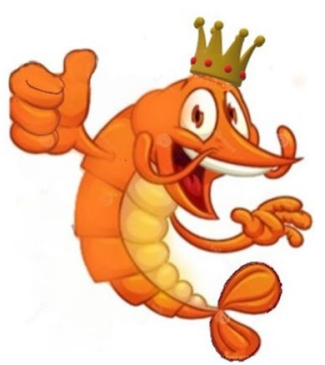

Vaccinated shrimp
Fig. 4 Effects of vaccination on shrimp aquaculture

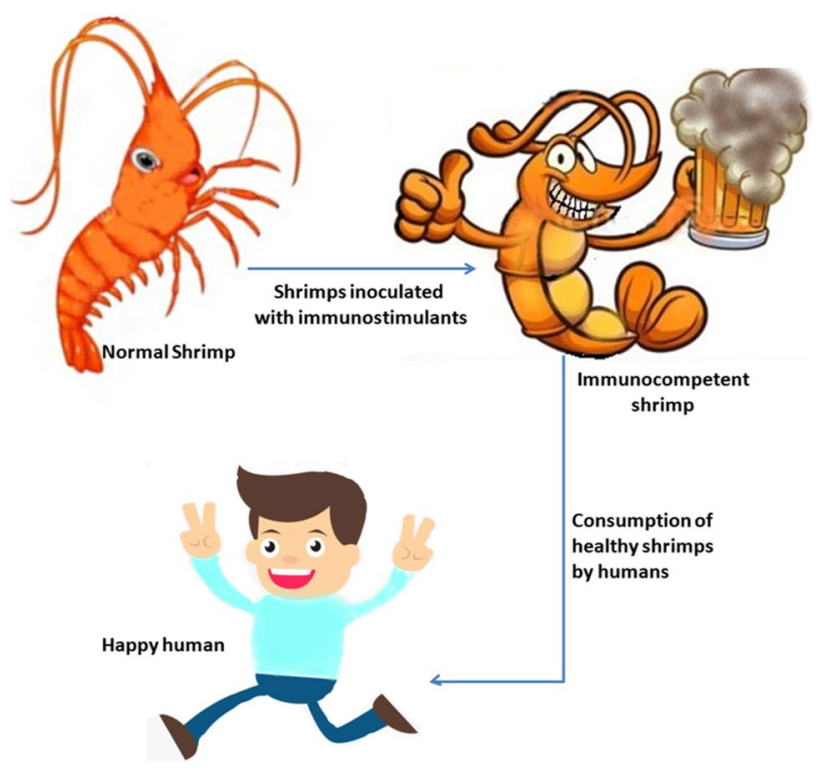

Fig. 5 Effects of immunostimulants on shrimp aquaculture and its environment

\section{Immunostimulants against WSSV}

An immunostimulant is a naturally occurring substance that simulates the immune system of host against pathogens (Barman and Nen 2013). Immunostimulants can be divided into several groups depending on their sources: bacterial, algae-derived, animal-derived, nutritional factors, and hormones/cytokines (Sakai 1999). Recently, polysaccharides from seaweeds have also been tested as immunostimulants for shrimps (Declarador et al. 2014) (Fig. 6). They are broad range in efficacy and depict multitude of functions (Fig. 7). The multifarious antivirals available from variety of life forms are now discussed below.

\section{Plant-derived antivirals}

Plants serve as repository of secure and economic chemical compounds that depict various properties such as growth promoters, immunostimulants, and antimicrobials (Citarasu et al. 2002). These have an upper hand because they consist of compounds that are non-toxic, biodegradable, and biocompatible (Citarasu et al. 2006). Underneath effort was done to provide a detailed insight into various forms of immunostimulants and chemicals derived from plants that have been reported as antiviral against WSSV.

\section{Antiviral activity of genipin}

Genipin (GN) is a bioactive compound obtained from the fruits of Gardenia jasminoides (Huang et al. 2019). GN is an aglycone obtained from an iridoid glycoside called 
Fig. 6 Sources of immunostimulants
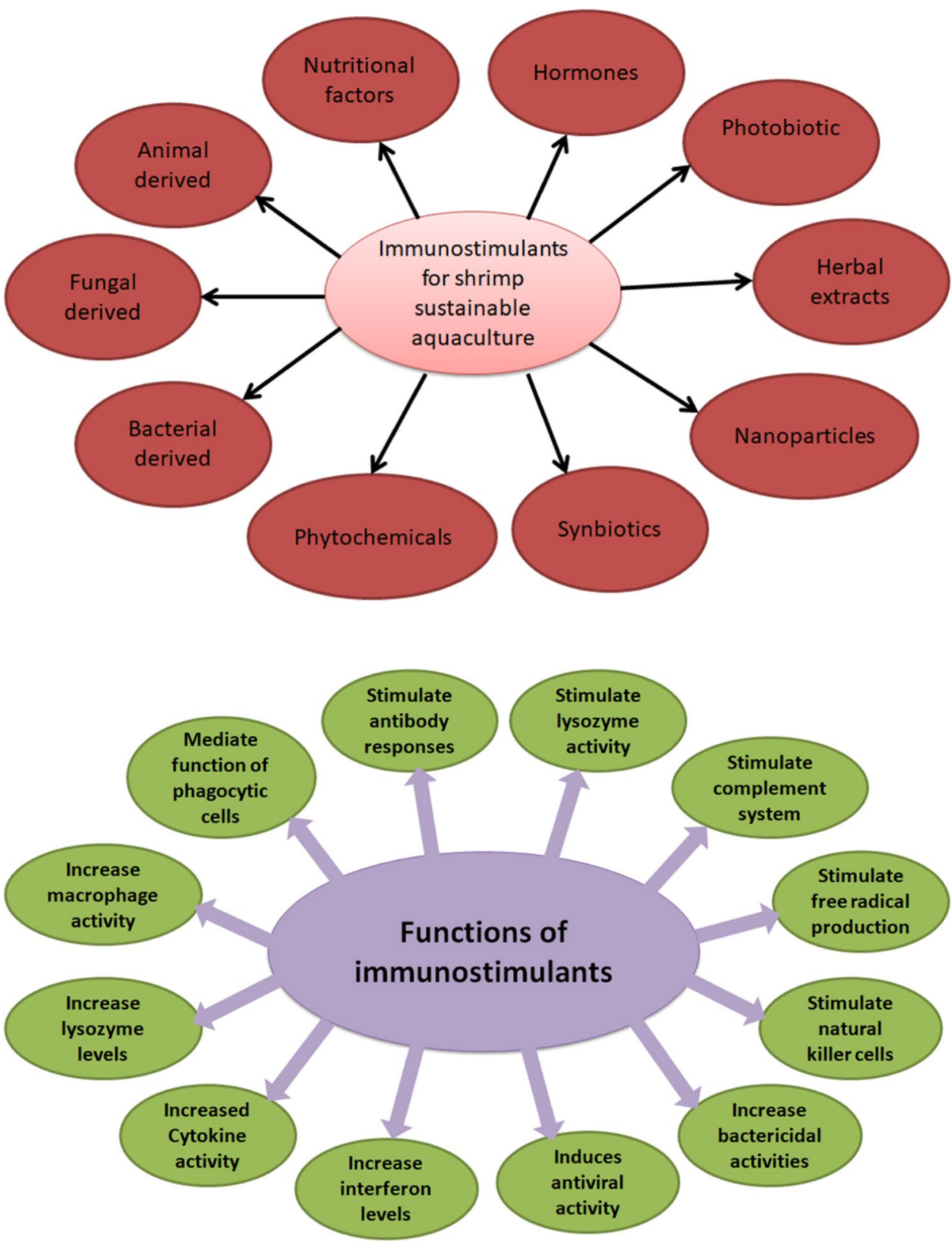

Fig. 7 Function of immunostimulants geniposide. It is a natural cross-linker that has low toxicity and excellent biocompatibility. Therefore, it is used for synthesizing diverse biological polymers for drug delivery purpose (Sung et al. 2001; Mahgoub et al. 2017). It depicts anti-inflammatory, neuroprotective, antidiabetic, antiproliferative, antioxidative, and antiviral activities (Wang et al. 2017). Lately, the antiviral activity of GN against WSSV has been illustrated in crayfish Procambarus clarkii and in shrimp Litopenaeus vannamei. The infection caused by WSSV was impeded to the maximum level when the crayfish and shrimps were treated with $50 \mathrm{mg} / \mathrm{kg}$ of $\mathrm{GN}$ for a day. A detailed insight into the mechanism showed that GN deteriorates gene expression of signal transducer and activator of transcription (STAT), which in turn obstructs transcription of WSSV immediate-early gene, thus finally retarding WSSV replication. Moreover, it also caused the inhibition of Bax inhibitor-1 gene expression, which contributed further to inhibition of WSSV infectivity. Hence, GN is presumed to be an effective remedy to occlude WSSV infection (Huang et al. 2019).

\section{Immunostimulant from various herbs}

Oral administration of immunostimulants like lipopolysaccharides, etc. has shown increase in defensive effectiveness in WSD (Citarasu et al. 2003). Recently, a variety of herbal 
extracts have demonstrated their ability to augment immunity in shrimp against yellow head virus YHV and WSSV (Citarasu et al. 2003). Immunostimulants from 5 diverse herbal medicinal plants such as Eclipta alba, Aegle marmelos, Tinospora cordifolia, Picrorhiza kurooa, and Cyanodon dactylon depicted significant reduction in the viral load with increase in survival rate (74\%) of shrimps (Citarasu 2010). Five herbs such as Adathoda vasica, Agathi grandiflora, Leucas aspera, Psoralea corylifolia, and Quercus infectoria have been used to screen the antiviral and immunostimulant activity against WSSV using different organic polar and nonpolar solvents. Ethyl acetate and methanolic extracts of $A$. grandiflora depicted strong antiviral and immunostimulant activities. Compounds such as 1,2-benzenedicarboxylic acid, diisooctyl ester in the A. grandiflora extract-enriched diets helped to control the WSSV in shrimps (Bindhu et al. 2014). The shrimp species which were not subjected to any immunostimulant completely died in 3 days while the one who were inoculated with $A$. grandiflora extract-enriched diets showed reduction in the cumulative mortality of shrimps up to $60-80 \%$ (Bindhu et al. 2014).

\section{Antimicrobials from Argemone mexicana}

A. mexicana is a species of poppy that has medicinal properties and used by people in parts of Mexico, western US, and India. A. mexicana is employed to cure numerous illnesses including tumors, lumps, skin diseases, inflammations, painful joints, leprosy, malaria, and microbial infections. Such ailments can be treated due to diversified chemical constituents of plant that includes various alkaloids, mexicanol, mexicanic acid, argemonic acid, and phenolics (Palanikumar et al. 2018). Its seeds contain argemone oil that is composed of alkaloids such as sanguinarine, dihydrosanguinarine, dehydrocorydalmine, jatrorrhizine, columbamine, and oxyberberine (Gunstone et al. 1977). Variety of other alkaloids like cheilanthifoline, berberine, cryptopine, muramine, protopine, sanguinarine, stylopine, and thalifoline have also been described in the recent years (Singh et al. 2010). Methanolic and ethanolic extracts of the plant have potent astringent, antioxidant hepatoprotective activities, and antimicrobial properties (Dash and Murthy 2011).

A. mexicana roots possess antioxidant activity and therefore can be used as restorative agent in pacifying oxidative stress-associated degenerative diseases (Perumal et al. 2010). The methanolic extract accelerates the wound healing in wounded rats because of the phytochemicals like triterpenoids, alkaloids, flavonoids, and tannins. The proPO system then stimulates the production of antioxidant enzymes such as reactive oxygen intermediates (ROI) and reactive nitrogen intermediates (RNI), antimicrobial peptides, and lysozymes that eventually lead to phagocytosis. The fraction of shrimp group kept in control conditions succumbed $100 \%$ death in just 4 days, while the shrimp group subjected to A. mexicana extracts depicted the survival up to $79 \%$.

\section{Antiviral activity of bis(2-methylheptyl)phthalate from Pongamia pinnata leaves}

Pongamia glabra vent (family Leguminosae) is an aboriginal ethnomedical plant found throughout India, tropical Asia, and Northern Australia. It is a moderate sized, expeditiously growing, and resilient plant that thrives under wide range of agroclimatic conditions and commonly occurs around roadsides, river banks, tidal forests, and even coastal areas. Its dried leaves when stored in the stocked grains serve as insect repellent. Its leaves decrease nematode infections tremendously when used as part of manure. The leaves of the plant are popularly known for its digestive, laxative properties, curing piles, lacerations, and extra soreness too. The juice of the leaves can be consumed to reduce flatulence, dyspepsia, diarrhea, cough, leprosy, and gonorrhea. The bark and roots of the plant are bitter in nature and therefore have anthelmintic properties (Al Muqarrabun et al. 2013). Feeding the purified ethanolic extract of $P$. pinnata leaves orally to WSSV-infected $P$. monodon increased the survival chances of the shrimps. Bis(2-methylheptyl)phthalate was responsible for the antiviral nature of $P$. pinnata. When WSSVinfected shrimp were fed with $200 \mathrm{~g}$ and $300 \mathrm{~g}$ extracts of P. pinnata, their survival rates improved by $40 \%$ and $80 \%$, respectively (Rameshthangam and Ramasamy 2007).

\section{Immunomodulatory effect of polysaccharide gel extracted from Durio zibethinus}

D. zibethinus is the most prevalent tree species in the genus Durio most commonly found in South Asia especially Thailand. Its fruit is brown-green in coloration and exhibits presence to massive spiny thorns. The durian-rind waste is economically viable and produces polysaccharides with pharmaceutical and therapeutic uses (Pongsamart et al. 2005). The polysaccharide gel (PG) of durian rinds has been extracted, refined, and characterized (Hokputsa et al. 2004), and is now known to be a water-soluble pectic polysaccharide. The structure was deciphered and detail introspection revealed that the structure contains polygalacturonic acid with side chain made up of neutral sugars such as rhamnose, arabinose, glucose, galactose, and fructose. Regarding the bioactivity of the PG, it was discovered that it is antibacterial and also possesses wound-healing activities and immunomodulating properties (Chansiripornchai and Pongsamart 2008). Hence, PG extract from Durio zibethinus was tested as an immunostimulant to check the immunocompetency in shrimp against WSSV.

Shrimps that were given 1 and $2 \%$ of PG as diet for a period of 12 weeks demonstrated accelerated proPO activity 
as well as elevated values of THC $(P<0.05)$ when compared to the control group that was fed the basal diet without PG. Such results clearly suggested that the shrimp population in which PG-supplemented diet was orally administration emerged to be resistant to WSSV. Hence, the observed disease resistance in shrimps against WSSV may be attributed to the aggravated immune response of shrimps. Shrimps fed with 2\% PG-supplemented diet indicate disease resistance of $36 \%$ (at day 4) and 100\% (at day 6) (Pholdaeng and Pongsamart 2010).

\section{Antiviral extract from Cyanodon dactylon}

In another study, antiviral plant extract derived from Cyanodon dactylon was injected both by in vitro as well as in vivo process. In in vitro method, the extract was injected intramuscularly while in in vivo process, it was fed orally at concentration of $2 \mathrm{mg}$ per animal. When $C$. dactylon plant extract was inoculated in WSSV-infected shrimps, then proPO, $\mathrm{O}^{2-}$, and $\mathrm{NO}$ got considerably high $(P<0.05)$ in values. Such evidence strongly suggests that inoculation of $C$. dactylon plant extract both by in vivo and in vitro procedures into shrimps enhances immunity of the shrimps. Additionally, the plant extract is very easily accessible and can serve as an excellent pre-emptive agent against WSSV disease in shrimps (Balasubramanian et al. 2007).

\section{Phytochemicals as immunostimulants}

An assortment of heterocyclic synthetic compounds like benzisoxazoles and piperidines has been found to play significant roles against microbial pathogens (Rajashekar Reddy et al. 2016). Furthermore, in silico studies provide a deeper knowledge for developing novel inhibitor against WSSV. The computational studies divulge that phytocompounds 2H-1-benzopyran-6-ol, 3,4-dihydro-2,5,7,8-tetramethyl-2-(4,8,12-trimethyltridecyl)-acetate, and 1,4-benzenediamine, N,N0-diphenyl identified from Phyllanthus amarus can serve as candidate molecules for WSD management (Dinesh et al. 2017). Another phytochemical known as quercetin has been predicted to be the suitable lead as it interacts with PmRab7 (one of the most crucial shrimp receptor proteins). Hence, use of this compound during maintenance of shrimp population in ponds, tanks, or natural reservoirs might diminish the interactions between Peneaus monodon PmRab7 and the viral proteins (Joseph et al. 2017).

A polyphenolic extract of red raspberry (Rubus idaeus) has shown to cluster viral particles cohesively to form noninfectious aggregations (Fukuchi et al. 1989). The polyphenols have further been reported to get associated with the virus particles directly thereby inhibiting the viral absorption into the host. Moreover, numerous polyphenolic compounds have been found to decrease association between human immunodeficiency virus (RNA virus) and influenza virus (RNA virus) with the host cells. Recently, 2,4-di-tertbutylphenol extracted from Emilia sonchifolia (a medicinal herb) has been recognized to have anti-WSSV and anti8 YHV (Maikaeo et al. 2015) properties and, therefore, it has been suggested to be fed to shrimp in order to boost resilience against virus-induced disease (Citarasu et al. 2006).

Anti-inflammatory activities of coumarins, which are naturally occurring pharmacologically active chemicals, are infinitely strong and efficient (Liu et al. 2020). This structure is made up of a benzo-pyranolactone moiety. Coumarins are divided into four categories: (i) simple coumarins, (ii) furanocoumarins, (iii) pyranocoumarins, and (iv) pyronesubstituted coumarins. They have a wide range of noncovalent interactions that allow them to bind to a variety of active sites. Some of the diversified functions in which coumarins majorly contribute are as follows: antioxidants (Minhas et al. 2017), antibacterials (Dastan et al. 2016), antiinflammatory (Sahu et al. 2017), anticancer (Zhang et al. 2019), and antiviral (Kostova et al. 2006). Anti-diabetic drugs, HIV, cancer, and degenerative disorders may all benefit from the use of hydroxycoumarin derivatives in animals (Shen et al. 2010). There is a lot of potential for coumarins to be employed as antiviral medications in aquaculture because of their widespread usage as phytochemicals. Carp virus (SVCV) expression in host cells may be inhibited by 7-[6-(2-methylimidazole)-hexyloxy] coumarin (a coumarin derivative), which has been used as a potent antiviral medication (Chen et al. 2018). Epithelial papulosum cyprinid cells may be successfully treated with imidazole-coumarin compounds with four-carbon linker lengths (Liu et al. 2020). A coumarin derivative, chromene-3-carbonitrile widely known as C3007 used in Litopenaeus vannamei larvae, was tested for its anti-WSSV function. More than half of WSSVinfected larvae were able to survive for longer after taking C3007. Continued immersion in C3007 resulted in a 20\% decrease in mortality after a 24-h WSSV infection. Hence, coumarin and its derivatives can be a viable treatment and prevention option for farmed shrimp WSSV infection.

\section{Antivirals from bacteria}

Other alternatives used as protection against WSD were oral inoculation of baculovirus and Bacillus subtilis spores (Syed Musthaq et al. 2009; Nguyen et al. 2014). RNA interference (RNAi) was also used to restrain the expression of viral proteins for inducing immunity in the host against WSD. It is elusive that $M$. japonicus has a potential to generate small interfering RNA (siRNA), which targets vp28 (vp28-siRNA) in reaction to WSSV infectivity. This further indicates that RNAi has a shielding effect for the host (Huang and Zhang 2013). In another contemporary work, when vp28-siRNAs encapsulated with $\beta$-1,3-d-glucan were injected along 
with WSSV in M. japonicas (Zhu and Zhang 2012), there occurred tremendous inhibition of WSSV replication.

The studies made till date laid a lot of importance on increasing the immune competency of the host. It can be done by catering the host with agents containing pathogenassociated molecular patterns (PAMPs). Studies have illustrated that feeding $P$. japonicus with peptidoglycans over a time span has escalated the phagocytic activity of host granulocytes therefore significantly decreasing mortality of P. japonicus upon WSSV exposure (Itami et al. 1998). Similarly, injecting $\beta$-glucan in shrimp prior to WSSV infection activated prophenoloxidase system and consequently caused reduction of morbidity in shrimps up to $25-50 \%$ when compared to control system (Song et al. 1994). They boost innate immunological responses such as phagocytic activation, neutrophil activation, alternative complement system stimulation, and enhanced lysozyme activity (Kyu et al. 2014).

Vibrio is a rod-shaped gram-negative bacteria and has been documented to reduce mortality in shrimps (Itami et al. 1989). The non-specific immune cells of shrimps such as phagocytic hemocytes are activated (Sakai 1999) by use of Vibrio. The bacterium Vibrio harveyi was reported to defend $P$. monodon against WSSV infection. Another important bacterial component is lipopolysaccharide (LPS). LPS are the major component of the outer membrane of gramnegative bacteria that can stimulate immune responses in different hosts. They are constituted by lipid and a polysaccharide that are joined by a covalent bond. The lipid in conjunction with polysaccharide is considered to be responsible for the biological activities of LPS (Rietschel et al. 1993). The immunostimulatory activity of LPS has been depicted in shrimps. Shrimps fed with LPS-containing diet depicted higher survival rates in comparison to the one fed with normal diet. Receptors such as anti-lipopolysaccharide factor 3 (ALF3), C-lectin, and mucin-like peritrophin located on shrimp digestive tracts were induced on using LPS-containing diet. Thus, LPS-supplemented diet was considered to be an efficient immunostimulant for Peneaus monodon (Rungrassamee et al. 2013). Another form of immunostimulants can be live bacteria. When shrimp feed is supplemented with probiotic bacteria, the cellular and humoral components of the innate immune system of shrimps get stimulated. Immunostimulation of Penaeus monodon by Bacillus S11 bacteria boosted phagocytic activity. Lactobacillus plantarum treatment increased phenoloxidase and superoxide dismutase activity, resulting in improved Vibrio alginolyticus clearance efficiency in Litopenaeus vannamei (Chiu et al. 2007).

\section{Antivirals from algae}

Seaweeds are multicellular algae that have been conceded to be a significant resource to develop resistance against pathogens for aquaculture because of prevalence of bioactive compounds, such as laminarin, fucoidan, carrageenan, and alginate that act as immunostimulants for the aquatic species. Furthermore, brown seaweeds have lately been reported as a source of polysaccharides and exhibit property of therapeutic agents and antibiotics for aquatic species. Fucoidan containing extracts from Sargassum spp. and from Cladosiphon okamuranus seaweed provide some resistance to WSD in Penaeus monodon and Marsuspenaeus japonicus (Immanuel et al. 2012), respectively. Recent studies have revealed that fucoidan plays an imperative role in the defensive mechanism of shrimp through mediating the cellular and the humoral responses in order to confront with the virus. It hampers the absorption of viral particles and facilitates the genesis of virus-induced syncytium. Feeding fucoidan orally is presumed to have defensive effects through inhibition of viral replication directly as well as triggering the innate immune defense responses.

It is seen that sodium alginate obtained from brown algae Undaria pinnatifida and Macrocystis pyrifera has potential to aggravate the nonspecific defense response of common carp Cyprinus carpio to Edwardsiella tarda (Fujiki et al. 1994). In similar manner, alginate obtained from brown algae $U$. pinnatifida and Lessonia nigrecans boosts Litopenaeus vannamei resistance to $V$. alginolyticus. Another study showed that sodium alginate availed from brown seaweed Sargassum wightii and primed in form of powder/beads was used to supplement Artemia nauplii. Such alginate-enriched nauplii when catered to Penaeus monodon could potentially impede succession of WSSV disease. When mortality between alginate-fed shrimp groups and control groups was compared, it was detected that mortality increases in alginate-fed groups by 26.5 to $58.4 \%$.

More recently, a screening study was performed to check efficiency of Cereops tagal mangrove extracts against WSSV activity in P. monodon (Sudheer et al. 2011), and Litopenaeus vannamei immersed in the seawater containing Sargassum hemiphyllum var. chinensis powder. A significant increase in the defensive mechanism of such P. monodon (Sudheer et al. 2011) and Litopenaeus vannamei was depicted with increased protection against Vibrio alginolyticus and WSSV (Huynh et al. 2011).

\section{Antivirals from fungi}

A marine yeast Candida aquaetextoris S527 was used as diet for $P$. monodon with varying proportions, viz., single dose every day, once in 3 days, once in 7 days, and once in 10 days followed by challenge with WSSV. Following induction of this feed, the immune parameters such as total hemocyte count, pro-phenoloxidase, nitroblue tetrazolium reduction, and acid phosphatase activity were tested on the shrimps. The expression profiling of immune-associated 
proteins and pathways such as antimicrobial peptide (AMP) genes, alpha-2-macroglobulin (a-2-M) genes, prophenol oxidase (proPO) genes, and WSSV genes was further analyzed. The investigation established that when the yeast feed was inoculated one time every 7 days, then it worked as a superior immunostimulant against WSSV infection (Babu et al. 2013).

There are a wide range of components in yeast that are of nutritional benefit to humans and other animals, including proteins, carbohydrates, lipids, vitamins, and minerals. Yeast extracts are made up of water-soluble components of yeast cells, such as amino acids, peptides, carbohydrates, and salts, which are their primary constituents. Because of their nutritional properties, nitrogen components and vitamins are of the utmost economic significance. In recent years, yeasts have been shown to exhibit antioxidant and immunostimulating properties. Bakery and brewer's yeast produce naturally occurring polysaccharides containing glucose as a structural component, connected by $\beta$-glycocidic linkages (Saccharomyces genus). Saccharomyces cerevisiae, the yeast used in the brewing process, contains a variety of compounds, including the sugars glucans and nucleic acids as well as the mannan-oligosaccharides that have been shown to improve immune responses and growth in a variety of fish species (Ortuño et al. 2002). Brewer's yeast $\beta$-glucan (BYG) has been shown to have enhanced phenoloxidase activity, and oral treatment of BYG for 3 days to black tiger shrimp (Suphantharika et al. 2003) boosted their ability to kill Vibrio harveyi (Thanardkit et al. 2002). Pacific Food supplemented with an inactive yeast cell wall had no effect on the shrimp's weight, survival rate, or growth rate; yet they exhibited stronger immunological measures (total hemocyte count, clearance of microorganisms) than shrimp given a standard diet (Chotikachinda et al. 2008).

\section{Antivirals from animals}

In some studies, animals have also been utilized to extract antivirals in order to cure WSSV in shrimps. In a recent study, cathelicidin 5, a type of peptide was obtained from Alligator sinensis and used as antimicrobial peptide against WSSV in caridean shrimp Exopalaemon modestus. Shrimp medicated with cathelicidin 5 and injected with WSSV revealed an appreciably lower mortality rate, lower viral VP28 amplification rate, and improved antioxidant enzyme activity and immune-related gene expression in shrimp Exopalaemon modestus (Xie et al. 2019).

Furthermore, the compound 3-(1-chloropiperidin-4-yl)6-fluoro benzisoxazole 2 has been identified as a suitable antiviral curative agent in freshwater crabs Paratelphusa hydrodomous against WSD (Rajashekar Reddy et al. 2016). The same compound was tested against WSSV in shrimps by employing in silico methodologies such as molecular docking and molecular dynamics. The computational analysis revealed that the inhibitor binds to the polar amino acids that line the pore region of the envelope proteins. The delineation of the inhibitor molecule within the binding pocket is much plausible due to the low binding energy against VP26 and VP28. This makes the inhibitor a preferred antiviral lead against WSSV (Rajashekar Reddy et al. 2016).

Similarly, chitosan has been proposed to be a good immunostimulant. Chitin is a polysaccharide prevalent in insects, crustacean exoskeletons, and fungal cell walls, and is one of the most ubiquitous polysaccharides in nature (Esteban et al. 2005). Chitosan is derived from the alkaline deacetylation of crustacean chitin. Chitin and chitosan have been shown to protect fish and shrimp from bacterial infection when given as an injection, immersion, or dietary supplement (Siwicki et al. 1994).

\section{Immunostimulants from synthetic sources}

Currently, nanotechnology is being used to study the biological systems in much intricate detail at the atomic level (Parveen et al. 2012; Esmaeillou et al. 2017). Silver nanoparticles (AgNPs) are presently serving as very promising nanomaterials because they render comprehensive antiviral property (Galdiero et al. 2011; Bello-Bello et al. 2018; Chris et al. 2018). Multifarious studies have confirmed that AgNPs are a potential antiviral substitute against human viruses, including human immunodeficiency virus (Lara et al. 2010), H1N1 influenza A virus, monkeypox virus (Rogers et al. 2008), Tacaribe virus (Speshock et al. 2010), and herpes simplex virus (Baram-Pinto et al. 2009).

Many studies have elucidated wide usage of AgNPs in many intricate details against enveloped viruses and such studies have confirmed that AgNPs preferentially bind to the viral envelope glycoproteins to hinder the binding between viruses and host cell (Lara et al. 2011; Bogdanchikova et al. 2016). Additionally, immune system can recognize the nanoparticles very well and these particles help in inducing immunostimulatory effects in the immune system (Boraschi et al. 2017; Dacoba et al. 2017).

A pivotal step taken in applying nanotechnology in aquaculture was making use of AgNP-based formulations. One such formulation, Argovit R, was inoculated in the form of intramuscular injections into L. vannamei (RomoQuiñonez et al. 2020). An observation was deduced that silver nanoparticle single dosages can alone enhance the shrimp survival tremendously without toxic effects, thus proving its antiviral activity against WSSV. Another study evaluated that Argovit $R$ promoted the immune response of shrimp infected with WSSV even under unfavorable circumstances, for example elevated concentration of $\mathrm{Fe}^{+2}$ ions in the medium (Ochoa-Meza et al. 2019). Thus, AgNPs can be used as an effective agent against a large 
heterogeneous form of viruses, especially against WSSV, although intramuscular administration of AgNPs is practically not feasible due to large volumes of organisms that need to be treated. A realistic substitute for intramuscular administration of AgNPs is incorporating AgNPs in the form of feed (Dananjaya et al. 2016). This will assure the applicability of AgNP to evade WSSV infection in shrimps. A new formulation named Argovit-4 (that essentially retains same design of Argovit R) has been recently reported as a propitious antiviral additive in feed to interfere with WSSV infection in shrimp. The most characteristic attributes that contribute to make Argovit-4 as a potential candidate for antiviral therapy in shrimps are (i) its decreased/increased concentrations do not cause toxicity to shrimps, (ii) intramuscular administration of a mixture of WSSV-Argovit-4 potentially decreased shrimp mortality at least by $50 \%$, and (iii) it shows unaltered expression of PEN4, PAP, Crustin, and Rab6 genes suggesting that it does not interfere with immune system of shrimps (RomoQuiñonez et al. 2020).

\section{Immunostimulants from nutritional factors}

There was a marked increase in resistance of shrimps against the pathogens when they are injected with vitamins A, C, and E supplements (Lee and Shiau 2004). Similarly, carotenoids depict functions such as lymphocyte blastogenesis, lymphocyte cytotoxicity activity, stimulate the production of certain cytokines, and aggravate the phagocytic and bacterial killing ability of neutrophils and macrophages. In shrimps, dietary carotenoid supplementation enhanced stress resistance, salinity shock resistance, and antioxidant response before and after viral infection. Trace elements such as incorporation of copper in tiger shrimp resulted in escalated growth, total hemocyte count, and superoxide anion production. In white shrimp, nutritional supplementation with $\mathrm{Zn}$ improved immunological responses in a similar way (Lin et al. 2013).

\section{Immunostimulants from hormones}

Growth hormone $(\mathrm{GH})$ is a peptide hormone (also known as somatotropin or somatropin) that has numerous beneficial effects such as promotion of lipolysis, gluconeogenesis, increase in protein synthesis and stimulation of immune responses among others. In shrimp larvae, a recombinant bovine growth hormone has been demonstrated to improve development and immunity. In Macrobrachium rosenbergii, dietary supplementation of bovine lactoferrin (LF) improved immunological indices and resistance to Aeromonas hydrophila challenge in crustaceans (Chand et al. 2006).

\section{Mechanism of immunostimulation within shrimp body}

As stated above, shrimps lack adaptive immunity, but they have evolved a well-developed innate immune system in order to defend themselves from diseases. They have a hard exoskeleton as their first line of protection against pathogens (Aguirre-Guzmán et al. 2010). It contains calcium carbonate, carbohydrates, and proteins, and it aids in a variety of immune-related physiological functions (Mylonakis and Aballay 2005). Antimicrobials in the exoskeleton protect them against a variety of injuries and microbial attacks (Aguirre-Guzmán et al. 2010). After bypassing this initial line of protection, pathogens are able to make their way into the shrimps' hemocoel. The hemocoel is made up of a variety of hemocytes, which are the primary cells responsible to defend shrimp's body against invaders. In shrimps, three kinds of hemocytes have been hypothesized, namely, (i) hyaline (HCs) that participates in phagocytosis; (ii) granular (GCs) that get involved in melanization, antimicrobial peptides, and cytotoxicity; and (iii) semigranular cells (SGCs) that implicate encapsulation, early non-self-recognition, melanization, and coagulation (Jiravanichpaisal et al. 2006). Pathogen-associated molecular patterns (PAMPs) are unique patterns seen on pathogens that allow shrimp hemocytes to detect and destroy non-self materials (PAMPs). The shrimp innate system gets activated by the presence of invading pathogens since it is able to distinguish between the "non-self" cells of an invading pathogen and "self-cells" belonging to itself. Shrimp hemocytes recognize and eliminate nonself matter by recognizing specific patterns located on pathogen called pathogen-associated molecular patterns (PAMPs).The receptors located on hemocyte that recognize these PAMPs are called host pattern recognition proteins (PRPs). As soon as there is recognition between PAMPs and PRPs, the system is characterized by a cascade of cellular signals resulting in the release of antimicrobial factors. These cellular signals majorly include (i) pathogenesis, (ii) activation of reactive oxygen species (ROS) for respiratory burst, (iii) prophenoloxidase (proPO) system, and (iv) melanization that eventually kill and decompose the pathogen (Cerenius et al. 2010; Amparyup et al. 2013).

Hence, pattern recognition is the first step in innate immunity. Alike any infection, the immunostimulants also get detected in the hemocoel of shrimps by recognition of diversified PAMPs located on the immunostimulants. Any kind of antigen-specific responses to immunostimulants are not generated, but rather an overall response that accelerates the detection and clearance of a wide spectrum of infectious pathogens is stimulated by the introduction of 
immunostimulants (Secombes 1994). In addition, immunostimulants may be administered to aquatic animals by injection, bathing, or orally to increase their immune responses. Immunostimulants may be administered via injection; however, oral administration is preferred because of its non-stressful nature and extensive usage at little expense and effort, making it a more cost-effective option. To boost aquatic animals' immune systems, it may be necessary to include immunostimulants in the food (Harikrishnan et al. 2011).

In shrimp, different types of PRRs including (i) $\beta-1,3-$ glucanase-related proteins, (ii) $\beta-1,3$-glucan-binding proteins, (iii) c-type lectins, (iv) scavenger receptors, (v) galectins, (vi) fibrinogen related proteins, (vii) thioestercontaining down syndrome cell adhesion molecules, (viii) serine protease homologs, (ix) trans-activation response RNA-binding protein, and (x) TLRs have been reviewed (Wang and Wang 2013). Shrimp's innate immune system was activated by the binding of PRPs to pathogen-associated molecular patterns (PAMP), such as lipopolysaccharide from bacteria's cell walls or peptidoglycan (PG) from fungi's cell walls (Janeway 1989). After a successful recognition between PAMPs and PRPs, the serine proteinase cascade gets triggered and the PAMPs induced SGCs and GCs to degranulate, and release granules containing proPO system; then, proPO was converted to PO by active ppAE, resulting in the activation of melanization, releases of cytotoxic compounds, and encapsulation (Chen et al. 2016b). Additionally, two proPOs may be directly implicated in shrimp's acutephase immune defense, with proPO-II perhaps sometimes contributing sooner than proPO-I (Yeh et al. 2009).

Studies have been reported that after $L$. vannamei was induced with immunostimulant $10.6 \%$ pectin of cacao pod husks ( $\mathrm{pCPH}$ ), a recognition was established between $\mathrm{pCPH}$ and LGBP of $L$. vannamei. This resulted in marked increase of granulocytes, which further caused degranulation of $\mathrm{SGCs} / \mathrm{GCs}$ to further stimulate the proPO-II system. There was an evident increase in level of immunocompetence as depicted by aggravated levels of THC, GC, SGC, HC, and PO activity in shrimp's body. The phagocytic activity and clearance efficiency against $V$. alginolyticus in $L$. vannamei injected with pCPH clearly elevated after 1-7 days of injection (Lee et al. 2020).

Furthermore, newborn hemocytes are synthesized, matured, and released into the circulatory system by the hematopoietic tissue (HPT). Hemocyte homeostasis-associated protein (HHAP) has been found in the crayfish Pacifastacus leniusculus, P. monodon, and L. vannamei and is involved in hemocyte homeostasis. Astakine, an invertebrate cytokine that promotes HPT hematopoiesis and participates in cell differentiation, has been described in the crayfish P. leniusculus, P. monodon, and L. vannamei (Chen et al. 2016a). When $L$. vannamei was injected with fucoidan, a type of brown seaweed-based polysaccharide, the proliferation ratio and the number of mitotic cells were significantly increased in HPT, which resulted in an increase in THC, HCs, SGCs, and GCs, and the elevated levels remained for 7 days after injection of the immunostimulants (Lee et al. 2020). Fucoidan-treated shrimp had considerably increased phagocytic activity than saline-treated shrimp (25\%) after $48 \mathrm{~h}$. These shrimps also showed improvement in clearance efficiency against pathogens. Shrimp receiving fucoidan at either 48 or $144 \mathrm{~h}$ and subsequently confronted with $V$. alginolyticus had a substantially greater survival rate than control shrimp at 48-144 h post-challenge ( $p$ 0.05) (Chen et al. 2016a). Shrimp given diets containing fucoidan showed increased growth and immunological parameters, as well as resistance to $V$. alginolyticus and WSSV challenges in vivo experiments, as previously reported (Chen et al. 2016a). According to this research, the immunological parameters, HPT proliferation, phagocytic activity, and clearance of $V$. alginolyticus were evaluated. It was shown that shrimp treated with fucoidan maintained homeostasis in immunological parameters such as hemoglobin count and other immune markers, suggesting that shrimp treated with fucoidan might stay resistant to pathogens even if their immune markers returned to baseline levels (Chen et al. 2016a).

To summarize, immunostimulants are detected as foreign material when they enter the shrimp hemocoel. PRPs of shrimp hemocytes identify PAMPs on immunostimulants. When a certain pattern is recognized, a chain of events occurs that includes phogocytosis, melanization, and the creation of a hostile environment for the pathogen. These investigations show that shrimps' defense systems stay reinforced even if their immunological parameters return to their pre-stimulant levels, which aids in the clearing of pathogens (Lee et al. 2020).

Under these conditions, when pathogens enter a shrimp, then the hemocytes will transform from non-adhesive cells to sticky cells in order to aggressively attach to them. Encapsulation occurs when a multilayered sheath of cells is formed around the foreign invader. When it comes to phagocytosis, membrane invagination, the production of coated vesicles, and guided vesicle trafficking all play a role in this complicated process. Cellular defensive mechanisms such as phagocytosis, formation of nodules, encapsulation, and hemocyte motility are all stimulated by the proPO activating system (Yeh et al. 2009). Hydrogen peroxide, superoxide anion, and hydroxyl ions are produced by activated hemocytes to induce respiratory burst for creating an environment that is detrimental to the pathogen (Ancieta-Probstl et al. 2005).

Prophenoloxidase (PO), a crucial enzyme in the formation of melanin, is found in hemolymph as an inactive proenzyme (proPO). Enzyme ppAE activates proPO to $\mathrm{PO}$ which further 
oxidizes phenol into quinines which then polymerizes nonenzymatically to form melanin. This melanin is responsible for melanization reaction in which the melanin gets deposited around the pathogen and blackens it due to the action of phenoloxidase, an oxidoreductase (Ancieta-Probstl et al. 2005). An easy way to spot parasites in the blood or exoskeleton is to look for the "melanization response" or darkened spots in the cuticle. Hence, phagocytosis, encapsulation, respiratory bursts, and melanization, all these immunological processes work cumulatively towards attacking and killing the pathogen (Fig. 8). Thereafter, follows a pathogen clearance process in which pathogen debris is confined to gills and sinuses of the host hepatopancreas, from where they are expelled out of the shrimp (Aguirre-Guzmán et al. 2010).
Fig. 8 Mechanism of immunostimulation within shrimp body: the PAMP located on immunostimulants (IM) is recognized by PRP located on the hemocyte. This pattern recognition between IM and hemocyte activates the cascade of cellular signals that brings the shrimp's body into a state of elevated immune response. When a pathogen enters shrimp's body in such a state of aggravated immune response, then the PAMP of pathogen gets recognized by PRP of hemocyte, to cause phagocytosis, encapsulation, melanization, and nodule formation of the pathogen. All these immunological responses altogether eventually kill and decompose the pathogen

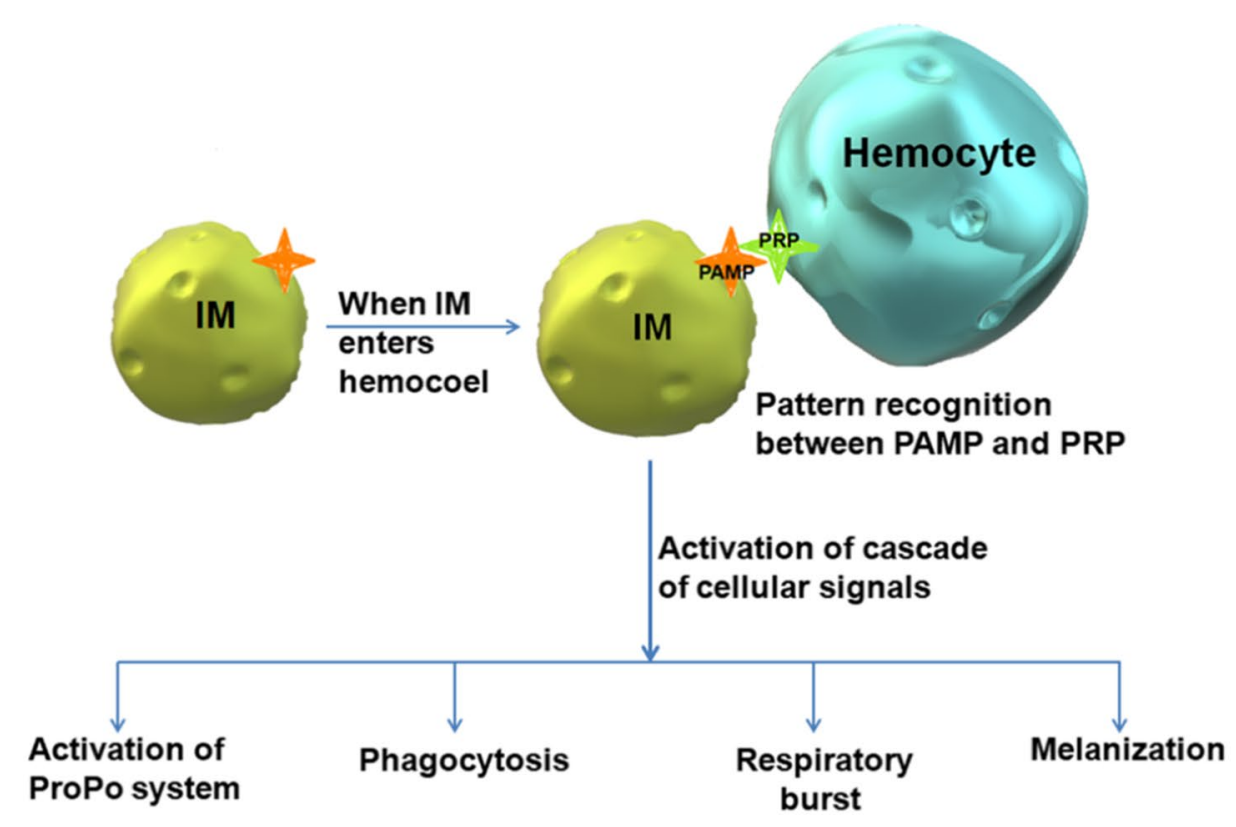

Shrimp body is in state of elevated immune response

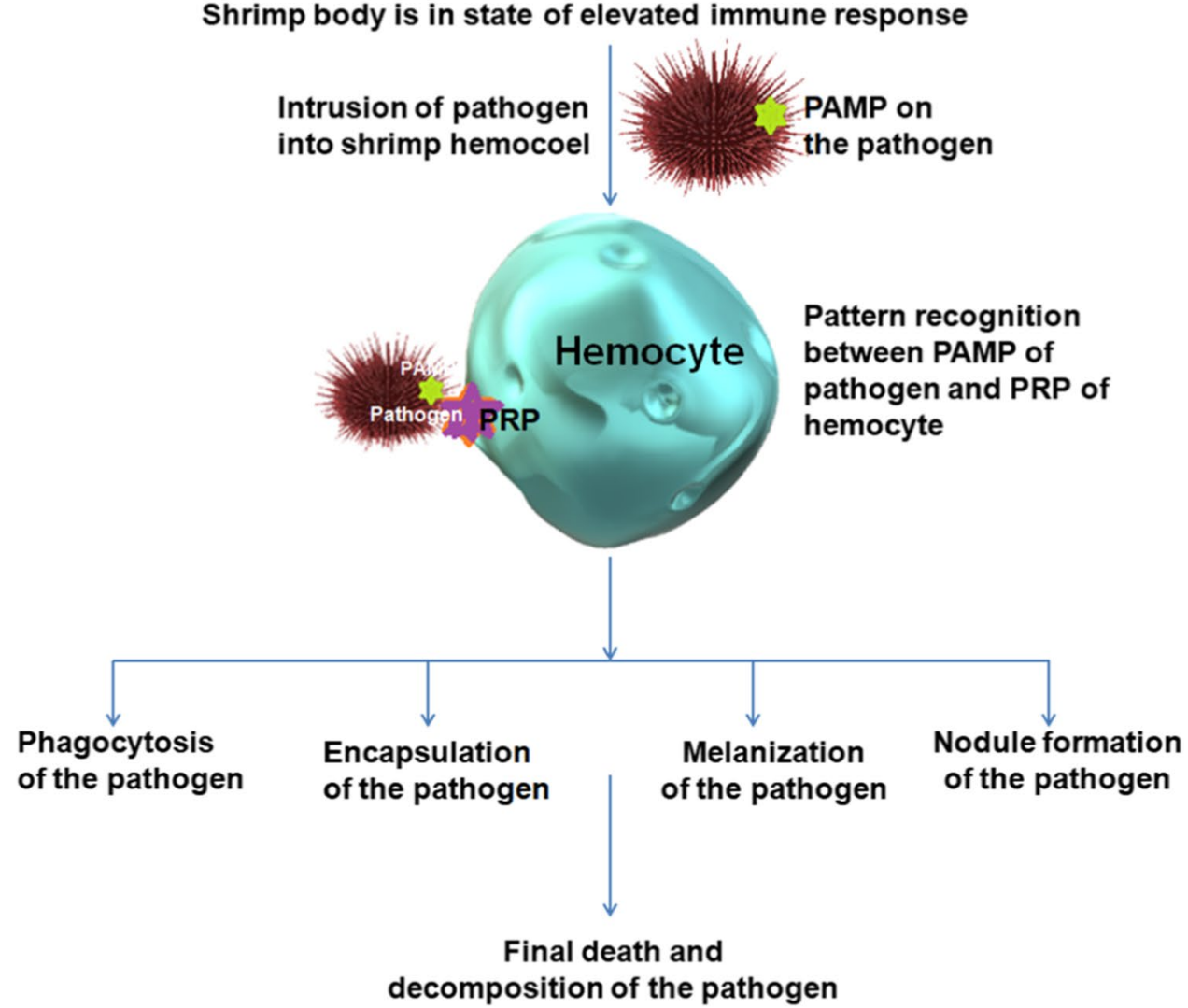




\section{Conclusion}

Shrimps constitute one of the most preferred commodities among the seafood for the humans. Despite the fact that they form part of most exquisite cuisines globally, there is a downside to shrimp aquaculture industry: the disease outbreaks. The aquaculture industry is gradually learning how to deal with these disease threats. The Snieszko's "epidemiological triad" has laid a lot of importance in shrimp health management. The reduction of stressful situations and the use of chemicals that strengthen and/or activate the shrimp immune system are other significant aspects of shrimp health management. In essence, these fundamentals correspond to the three elements of Snieszko's traditional epidemiological

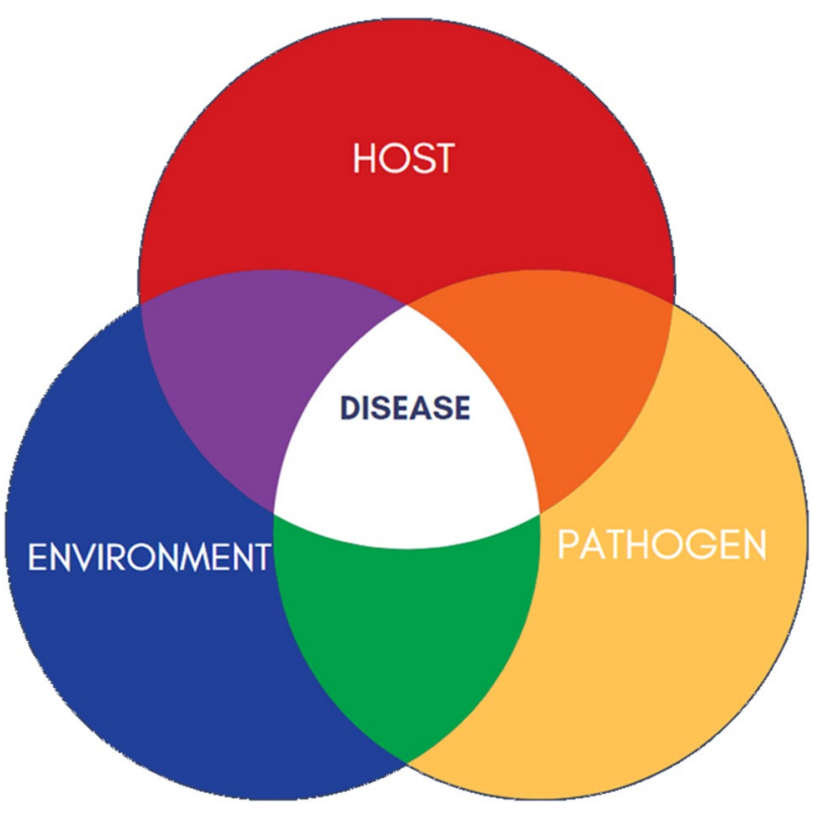

Fig. 9 Snieszko "epidemiological triad" and its application to shrimp health management triad: host, pathogen, and environment (Fig. 9). Thus, creating a balance between the components of the triad, viz., ensuring a pathogen-free stock, increasing host defense by giving nutrient/immunostimulants that strengthen immune system, pathogen-free water, and pathogen-free feed, and maintaining good water quality can promote sustainable shrimp aquaculture.

In order to combat the diseases, shrimp aquaculture industry embarked on usage of antibiotics. But introduction of antibiotics for fighting the disease leads to unnecessary biomagnification and bioaccumulation of toxic residues in the food web that further hampered human health too. Furthermore, due to the absence of innate immunity in shrimps, the possibility of using vaccination to successfully manage shrimp disease also looked unlikely. Looking into such a scenario, use of immunostimulants in order to increase the immunity of shrimps was a better answer to manage the shrimp health. A comparison between usage of antibiotics, vaccines, and immunostimulants has been mentioned (Table 1).

The various types of life forms including plants, animals, fungi, algae, and yeast serve as source of the natural medicine. They serve as most versatile, easily available, and low priced source of immunostimulants. When these immunostimulants were used as feed, the survival rates of shrimps increased somewhere from 40 to $80 \%$. Immunostimulants appear to be most promising and useful tools for prophylactic treatment of farmed fish and shrimp. It is safer than chemotherapeutics and their range of efficacy is wider than vaccination. The strength of these compounds appears to lie in their ability to enhance larval culture before the specific immune system matures, and the animals can be vaccinated and able to improve nonspecific immune function against a broad spectrum of pathogens (Barman and Nen 2013). Thus, employment of immunostimulants provides a "win-win" solution that augments the shrimp aquaculture as well as promotes human health. To eliminate pathogens and transporters of pathogens, pond bottoms must be disinfected after

Table 1 Comparison among antibiotics, vaccines, and immunostimulants for shrimp aquaculture management

\begin{tabular}{|c|c|c|c|}
\hline SR No & Antibiotics & Vaccines & Immunostimulants \\
\hline 1 & Non-prophylactic & $\begin{array}{l}\text { Prophylactic for long duration with } \\
\text { only one or two treatments }\end{array}$ & $\begin{array}{l}\text { Prophylactic for short duration, require more } \\
\text { treatments }\end{array}$ \\
\hline 2 & Costly & Costly & Cost effective \\
\hline 3 & Efficacy of antibiotics is good & Efficacy of vaccines is excellent & Efficacy of immunostimulants is good \\
\hline 4 & Limited spectrum of activity & Limited spectrum of activity & Wide spectrum of activity \\
\hline 5 & Toxic side effects can prevail & No toxic side effects & No toxic side effects \\
\hline 6 & $\begin{array}{l}\text { There might occur accumulation of toxic resi- } \\
\text { dues }\end{array}$ & No accumulation of toxic residues & No accumulation of toxic residues \\
\hline 7 & There can occur environmental impacts & No environmental impacts & No environmental impacts \\
\hline 8 & $\begin{array}{l}\text { Easy to provide antibiotics to all shrimps and } \\
\text { their larvae }\end{array}$ & $\begin{array}{l}\text { Difficult to vaccinate larvae and } \\
\text { individual shrimps }\end{array}$ & $\begin{array}{l}\text { Easy to provide immunostimulants to larvae as } \\
\text { well as individual shrimps }\end{array}$ \\
\hline
\end{tabular}


each culture cycle. The pond should be entirely emptied and well dried, or oxidizing chemicals should be used. It is also a good idea to clean up any organic trash that has gathered on the pond's bottom. Thus, amalgamation of proper sanitation practices and usage of immunostimulants to enhance the immune system of shrimps can lead to sustainable shrimp aquaculture.

Acknowledgements The authors are thankful to Vice-Chancellor, Maharaja Agrasen University, Himachal Pradesh, for providing facilities and constant encouragement.

Author contribution AA, AKV, and SK contributed to conceptualization of the review article; SK, AA, and AKV involved in writingoriginal draft preparation; AA, AKV, and SPS contributed in editing and critical revision.

Availability of data and materials Not applicable.

\section{Declarations}

Ethics approval Not applicable.

Consent to participate All authors declare they have given consent to participate in this article.

Consent for publication All authors declare they have given consent to publish this article.

Conflict of interest The authors declare no competing interests.

\section{References}

Aguirre-Guzmán G, Sánchez-Martínez JG, Pérez-Castañeda R et al (2010) Pathogenicity and infection route of Vibrio parahaemolyticus in American white shrimp, Litopenaeus vannamei. J World Aquac Soc 41:464-470. https://doi.org/10.1111/j.1749-7345. 2010.00388.x

Al Muqarrabun LMR, Ahmat N, Ruzaina SAS et al (2013) Medicinal uses, phytochemistry and pharmacology of Pongamia pinnata (L.) Pierre: a review. J Ethnopharmacol 150:395-420. https:// doi.org/10.1016/j.jep.2013.08.041

Amparyup P, Charoensapsri W, Tassanakajon A (2013) Prophenoloxidase system and its role in shrimp immune responses against major pathogens. Fish Shellfish Immunol 34:990-1001. https:// doi.org/10.1016/j.fsi.2012.08.019

Ancieta-Probstl D, Smullen R, Barnes A (2005) Enhancing growth performance of shrimp with nucleotide supplemented diets. Aquac Asiapacific 1:26-28

Apines-Amar MJS, Amar EC (2015) 3. Use of immunostimulants in shrimp culture: an update. Res Signpost 37661:45-71

Babu DT, Antony SP, Joseph SP et al (2013) Marine yeast Candida aquaetextoris $\mathrm{S} 527$ as a potential immunostimulant in black tiger shrimp Penaeus monodon. J Invertebr Pathol 112:243-252. https://doi.org/10.1016/j.jip.2012.12.002

Balasubramanian G, Sarathi M, Kumar SR, Hameed ASS (2007) Screening the antiviral activity of Indian medicinal plants against white spot syndrome virus in shrimp. Aquaculture 263:15-19. https://doi.org/10.1016/j.aquaculture.2006.09.037
Baram-Pinto D, Shukla S, Perkas N et al (2009) Inhibition of herpes simplex virus type 1 infection by silver nanoparticles capped with mercaptoethane sulfonate. Bioconjug Chem 20:14971502. https://doi.org/10.1021/bc900215b

Barman D, Nen P (2013) Immunostimulants for aquaculture health management. J Mar Sci Res Dev 03: https://doi.org/10.4172/ 2155-9910.1000134

Bello-Bello JJ, Spinoso-Castillo JL, Arano-Avalos S, et al (2018) Cytotoxic, genotoxic, and polymorphism effects on Vanilla planifolia Jacks ex Andrews after long-term exposure to argovit@ silver nanoparticles. Nanomaterials 8. https://doi.org/10. 3390/nano8100754

Béné C, Barange M, Subasinghe R et al (2015) Feeding 9 billion by 2050 - putting fish back on the menu. Food Secur 7:261-274. https://doi.org/10.1007/s12571-015-0427-z

Bindhu F, Velmurugan S, Donio MBS et al (2014) Influence of Agathi grandiflora active principles inhibit viral multiplication and stimulate immune system in Indian white shrimp Fenneropenaeus indicus against white spot syndrome virus infection. Fish Shellfish Immunol 41:482-492. https://doi.org/10.1016/j. fsi.2014.09.034

Bogdanchikova N, Huerta-saquero A, De NC et al (2016) Silver nanoparticles composition for treatment of distemper in dogs Roberto Vázquez-Muñoz Antonio Pena-Jasso Gildardo Aguilar-Uzcanga Alexey Pestryakov Vasilii Burmistrov Oxana Martynyuk Roberto Luna-Vázquez-Gómez and Horacio Almanza. Int J Nanotechnol 13:227-237

Bondad-Reantaso MG, Subasinghe RP, Josupeit H et al (2012) The role of crustacean fisheries and aquaculture in global food security: past, present and future. J Invertebr Pathol 110:158165. https://doi.org/10.1016/j.jip.2012.03.010

Boraschi D, Italiani P, Palomba R et al (2017) Nanoparticles and innate immunity: new perspectives on host defence. Semin Immunol 34:33-51. https://doi.org/10.1016/j.smim.2017.08. 013

Cabello FC (2006) Heavy use of prophylactic antibiotics in aquaculture: a growing problem for human and animal health and for the environment. Environ Microbiol 8:1137-1144. https://doi.org/10. 1111/j.1462-2920.2006.01054.x

Cerenius L, Jiravanichpaisal P, Liu HP, Söderhäll I (2010) Crustacean immunity. Adv Exp Med Biol 708:239-259. https://doi.org/10. 1007/978-1-4419-8059-5_13

Chand RK, Sahoo PK, Kumari J et al (2006) Dietary administration of bovine lactoferrin influences the immune ability of the giant freshwater prawn Macrobrachium rosenbergii (de Man) and its resistance against Aeromonas hydrophila infection and nitrite stress. Fish Shellfish Immunol 21:119-129. https://doi.org/10. 1016/j.fsi.2005.10.010

Chansiripornchai P, Pongsamart S (2008) Treatment of infected open wounds on two dogs using a film dressing of polysaccharide extracted from the hulls of durian (Durio zibethinus Murr.): case report. Thai J Vet Med 38:55-61

Chen YY, Chen JC, Kuo YH et al (2016a) Lipopolysaccharide and $\beta$-1,3-glucan-binding protein (LGBP) bind to seaweed polysaccharides and activate the prophenoloxidase system in white shrimp Litopenaeus vannamei. Dev Comp Immunol 55:144-151. https://doi.org/10.1016/j.dci.2015.10.023

Chen YY, Kitikiew S, Yeh ST, Chen JC (2016b) White shrimp Litopenaeus vannamei that have received fucoidan exhibit a defense against Vibrio alginolyticus and WSSV despite their recovery of immune parameters to background levels. Fish Shellfish Immunol 59:414-426. https://doi.org/10.1016/j.fsi.2016.10.050

Chen WC, Liu L, Shen YF et al (2018) A new coumarin derivative plays a role in rhabdoviral clearance by interfering glycoprotein function during the early stage of viral infection. Cell Signal 51:199-210. https://doi.org/10.1016/j.cellsig.2018.08.007 
Chiu CH, Guu YK, Liu CH et al (2007) Immune responses and gene expression in white shrimp, Litopenaeus vannamei, induced by Lactobacillus plantarum. Fish Shellfish Immunol 23:364-377. https://doi.org/10.1016/j.fsi.2006.11.010

Chotikachinda R, Lapjatupon W, Chaisilapasung S et al (2008) Effect of inactive yeast cell wall on growth performance, survival rate and immune parameters in pacific white shrimp (Litopenaeus vannamei). Songklanakarin J Sci Technol 30:687-692

Chou H-Y, Huang C-Y, Wang C-H et al (1995) Pathogenicity of a baculovirus infection causing white spot syndrome in cultured penaeid shrimp in Taiwan. Dis Aquat Organ 23:165-173. https:// doi.org/10.3354/dao023165

Chris UO, Singh NB, Agarwal A (2018) Nanoparticles as feed supplement on growth behaviour of cultured catfish (Clarias gariepinus) fingerlings. Mater Today Proc 5:9076-9081. https://doi.org/ 10.1016/j.matpr.2017.10.023

Citarasu T (2010) Herbal biomedicines: a new opportunity for aquaculture industry. Aquac Int 18:403-414. https://doi.org/10.1007/ s10499-009-9253-7

Citarasu T, Venkatramalingam K, Babu MM et al (2003) Influence of the antibacterial herbs, Solanum trilobatum, Andrographis paniculata and Psoralea corylifolia on the survival, growth and bacterial load of Penaeus monodon post larvae. Aquac Int 11:581-595. https://doi.org/10.1023/b:aqui.0000013322.53358. 53

Citarasu T, Sivaram V, Immanuel G et al (2006) Influence of selected Indian immunostimulant herbs against white spot syndrome virus (WSSV) infection in black tiger shrimp, Penaeus monodon with reference to haematological, biochemical and immunological changes. Fish Shellfish Immunol 21:372-384. https://doi.org/ 10.1016/j.fsi.2006.01.002

Citarasu T, Babu MM, Sekar RRJ, Marian MP (2002) Developing artemia enriched herbal diet for producing quality larvae in Penaeus monodon, Fabricius. Asian Fish Sci 15:21-32. https://doi.org/10. 33997/j.afs.2002.15.1.003

Dacoba TG, Olivera A, Torres D et al (2017) Modulating the immune system through nanotechnology. Semin Immunol 34:78-102. https://doi.org/10.1016/j.smim.2017.09.007

Dananjaya SHS, Godahewa GI, Jayasooriya RGPT et al (2016) Antimicrobial effects of chitosan silver nano composites (CAgNCs) on fish pathogenic Aliivibrio (Vibrio) salmonicida. Aquaculture 450:422-430. https://doi.org/10.1016/j.aquaculture.2015.08.023

Das S, Mondal K, Haque S (2017) A review on application of probiotic, prebiotic and synbiotic for sustainable development of aquaculture. J Entomol Zool Stud 5:422-429

Dash G, Murthy P (2011) Evaluation of Argemone mexicana Linn. Leaves for wound healing activity. J Nat Prod Plant Resour $1: 46-56$

Dastan D, Salehi P, Aliahmadi A et al (2016) New coumarin derivatives from Ferula pseudalliacea with antibacterial activity. Nat Prod Res 30:2747-2753. https://doi.org/10.1080/14786419.2016. 1149705

Declarador RS, Serrano AE, Corre VL (2014) Ulvan extract acts as immunostimulant against white spot syndrome virus (WSSV) in juvenile black tiger shrimp Penaeus monodon. AACL Bioflux 7:153-161

Dinesh S, Sudharsana S, Mohanapriya A, et al (2017) Molecular docking and simulation studies of Phyllanthus amarus phytocompounds against structural and nucleocapsid proteins of white spot syndrome virus. 3 Biotech 7:1-12. https://doi.org/10.1007/ s13205-017-0938-8

Esmaeillou M, Zarrini G, Rezaee MA, et al (2017) Vancomycin capped with silver nanoparticles as an antibacterial agent against multidrug resistance bacteria. Adv Pharm Bull 7:479-483. https://doi. org/10.15171/apb.2017.058
Esteban MA, Rodríguez A, Cuesta A, Meseguer J (2005) Effects of lactoferrin on non-specific immune responses of gilthead seabream (Sparus auratus L.). Fish Shellfish Immunol 18:109124. https://doi.org/10.1016/j.fsi.2004.06.003

FAO (2020) The state of world fisheries and aquaculture 2020. Sustainability in action.

Ferri N (2010) United nations general assembly. Int J Mar Coast Law 25:271-287. https://doi.org/10.1163/157180910X12665 776638740

Fujiki K, M H, Yano T, (1994) Protective effect of sodium alginates against bacterial infection in common carp, Cyprinus carpio L. J Fish Dis 17:349-355. https://doi.org/10.1111/j.1365-2761. 1994.tb00230.x

Fukuchi K, Sakagami H, Okuda T et al (1989) Inhibition of herpes simplex virus infection by tannins and related compounds. Antiviral Res 11:285-297. https://doi.org/10.1016/01663542(89)90038-7

Galdiero S, Falanga A, Vitiello M et al (2011) Silver nanoparticles as potential antiviral agents. Molecules 16:8894-8918. https://doi. org/10.3390/molecules16108894

Grave K, Lingaas E, Bangen M, Rønning M (1999) Surveillance of the overall consumption of antibacterial drugs in humans, domestic animals and farmed fish in Norway in 1992 and 1996. J Antimicrob Chemother 43:243-252. https://doi.org/10.1093/jac/43.2. 243

Gunstone FD, Holliday JA, Scrimgeour CM (1977) The long-chain oxo acids (argemonic acid) in Argemone mexicana seed oil. Chem Phys Lipids 20:331-335

Hallström E, Bergman K, Mifflin K et al (2019) Combined climate and nutritional performance of seafoods. J Clean Prod 230:402-411. https://doi.org/10.1016/j.jclepro.2019.04.229

Harikrishnan R, Balasundaram C, Heo MS (2011) Impact of plant products on innate and adaptive immune system of cultured finfish and shellfish. Aquaculture 317:1-15. https://doi.org/10. 1016/j.aquaculture.2011.03.039

Hirono I, Fagutao FF, Kondo H, Aoki T (2011) Uncovering the mechanisms of shrimp innate immune response by RNA interference. Mar Biotechnol 13:622-628. https://doi.org/10.1007/ s10126-010-9292-0

Hokputsa S, Gerddit W, Pongsamart S et al (2004) Water-soluble polysaccharides with pharmaceutical importance from durian rinds (Durio zibethinus Murr.): isolation, fractionation, characterisation and bioactivity. Carbohydr Polym 56:471-481. https://doi. org/10.1016/j.carbpol.2004.03.018

Huang AG, Tan XP, Qu SY et al (2019) Evaluation on the antiviral activity of genipin against white spot syndrome virus in crayfish. Fish Shellfish Immunol 93:380-386. https://doi.org/10.1016/j. fsi.2019.07.083

Huang T, Zhang X (2013) Host defense against DNA virus infection in shrimp is mediated by the siRNA pathway. 137-146. https:// doi.org/10.1002/eji.201242806

Huynh TG, Yeh ST, Lin YC et al (2011) White shrimp Litopenaeus vannamei immersed in seawater containing Sargassum hemiphyllum var. chinense powder and its extract showed increased immunity and resistance against Vibrio alginolyticus and white spot syndrome virus. Fish Shellfish Immunol 31:286-293. https://doi. org/10.1016/j.fsi.2011.05.014

Immanuel G, Sivagnanavelmurugan M, Balasubramanian V, Palavesam A (2012) Sodium alginate from Sargassum wightii retards mortalities in Penaeus monodon postlarvae challenged with white spot syndrome virus. Dis Aquat Organ 99:187-196. https://doi. org/10.3354/dao02466

Itami T, Takahashi Y, Nakamura Y (1989) Efficacy of vaccination against vibriosis in cultured kuruma prawns Penaeus Japonicus. J Aquat Anim Health 1:238-242. https://doi.org/10.1080/15488667(1989)001[1t]0238[co]EOVAVI[gt]2.3.CO;2 
Itami T, Asano M, Tokushige K (1998) Enhancement of disease resistance of kuruma shrimp, Penaeus japonicus , after oral administration of peptidoglycan derived from Bifidobacterium thermophilum. 277-288

Janeway CA (1989) Approaching the asymptote? Evolution and revolution in immunology. Cold Spring Harb Symp Quant Biol 54:113. https://doi.org/10.1101/sqb.1989.054.01.003

Janewey CJ, Medzhitov R (2000) Innate immune recognition: mechanisms and pathways. Immunol Rev 173:89-97

Jiravanichpaisal P, Lee BL, Söderhäll K (2006) Cell-mediated immunity in arthropods: hematopoiesis, coagulation, melanization and opsonization. Immunobiology 211:213-236. https://doi.org/10. 1016/j.imbio.2005.10.015

Johansson MW, Soderhall K (1989) Cellular immunity in crustaceans and the proPO system. Parasitol Today 5:171-176. https://doi. org/10.1016/0169-4758(89)90139-7

Joseph J, Bhaskaran R, Kaliraj M, Muthuswamy M (2017) 97320630013116.Pdf. 13:

Song K-K, Li D-F, Zhang M-C, Yang H-J, Ruan L-W, Xu X (2010) Cloning and characterization of three novel WSSV recognizing lectins from shrimp Marsupenaeus japonicus. Fish \& Shellfish Immunology 28(4):596-603. https://doi.org/10.1016/j.fsi.2009. 12.015

Kostova I, Raleva S, Genova P, Argirova R (2006) Structure-activity relationships of synthetic coumarins as HIV-1 inhibitors. Bioinorg Chem Appl 2006:1-9. https://doi.org/10.1155/BCA/ 2006/68274

Kyu S, Ram B, Kim D, et al (2014) Fish \& shell fish immunology prebiotics as immunostimulants in aquaculture : a review. Fish Shellfish Immunol 1-9. https://doi.org/10.1016/j.fsi.2014.06.016

Lara HH, Ayala-Nuñez NV, Ixtepan-Turrent L, Rodriguez-Padilla C (2010) Mode of antiviral action of silver nanoparticles against HIV-1. J Nanobiotechnology 8:1-10. https://doi.org/10.1186/ 1477-3155-8-1

Lara HH, Garza-Treviño EN, Ixtepan-Turrent L, Singh DK (2011) Silver nanoparticles are broad-spectrum bactericidal and virucidal compounds. J Nanobiotechnology 9:2-9. https://doi.org/10.1186/ 1477-3155-9-30

Lee MH, Shiau SY (2004) Vitamin E requirements of juvenile grass shrimp, Penaeus monodon, and effects on non-specific immune responses. Fish Shellfish Immunol 16:475-485. https://doi.org/ 10.1016/j.fsi.2003.08.005

Lee CL, Chang CC, Kuo HW, Cheng W (2020) Pectin of cacao pod husk, an efficient immunostimulant for white shrimp, Litopenaeus vannamei. Fish Shellfish Immunol 107:357-366. https:// doi.org/10.1016/j.fsi.2020.10.026

Lin S, Lin X, Yang Y et al (2013) Comparison of chelated zinc and zinc sulfate as zinc sources for growth and immune response of shrimp (Litopenaeus vannamei). Aquaculture 406-407:79-84. https://doi.org/10.1016/j.aquaculture.2013.04.026

Liu YC, Li FH, Dong B et al (2007) Molecular cloning, characterization and expression analysis of a putative C-type lectin (Fclectin) gene in Chinese shrimp Fenneropenaeus chinensis. Mol Immunol 44:598-607. https://doi.org/10.1016/j.molimm.2006.01.015

Liu L, Qiu TX, Song DW et al (2020) Inhibition of a novel coumarin on an aquatic rhabdovirus by targeting the early stage of viral infection demonstrates potential application in aquaculture. Antiviral Res 174:104672. https://doi.org/10.1016/j.antiviral.2019.104672

Mahgoub E, Kumaraswamy SM, Kader KH et al (2017) Genipin attenuates cisplatin-induced nephrotoxicity by counteracting oxidative stress, inflammation, and apoptosis. Biomed Pharmacother 93:1083-1097. https://doi.org/10.1016/j.biopha.2017.07.018

Maikaeo L, Chotigeat W, Mahabusarakam W (2015) Emilia sonchifolia extract activity against white spot syndrome virus and yellow head virus in shrimp cell cultures. Dis Aquat Organ 115:157164. https://doi.org/10.3354/dao02891

Medzhitov R, Janeway CA (1997) Innate immunity: the virtues of a nonclonal system of recognition. Cell 91:295-298. https://doi. org/10.1016/S0092-8674(00)80412-2

Minhas R, Sandhu S, Bansal Y, Bansal G (2017) Benzoxazole-coumarin derivatives : potential candidates for development of safer anti-inflammatory drugs. Der Chem Sin 8:146-157

Miranda CD, Zemelman R (2002) Antimicrobial multiresistance in bacteria isolated from freshwater Chilean salmon farms. Sci Total Environ 293:207-218. https://doi.org/10.1016/S00489697(02)00022-0

Mylonakis E, Aballay A (2005) Toll - lien quan RF3 -mylonakis2005. pdf. 73:3833-3841. https://doi.org/10.1128/IAI.73.7.3833

Nadala ECB, Loh PC (1998) A comparative study of three different isolates of white spot virus. Dis Aquat Organ 33:231-234. https:// doi.org/10.3354/dao033231

Nguyen ATV, Pham CK, Pham HTT et al (2014) Bacillus subtilis spores expressing the VP28 antigen: a potential oral treatment to protect Litopenaeus vannamei against white spot syndrome. FEMS Microbiol Lett 358:202-208. https://doi.org/10.1111/ 1574-6968.12546

Ochoa-Meza AR, Álvarez-Sánchez AR, Romo-Quiñonez CR et al (2019) Silver nanoparticles enhance survival of white spot syndrome virus infected Penaeus vannamei shrimps by activation of its immunological system. Fish Shellfish Immunol 84:10831089. https://doi.org/10.1016/j.fsi.2018.10.007

Ortuño J, Cuesta A, Rodríguez A et al (2002) Oral administration of yeast, Saccharomyces cerevisiae, enhances the cellular innate immune response of gilthead seabream (Sparus aurata L.). Vet Immunol Immunopathol 85:41-50. https://doi.org/10.1016/ S0165-2427(01)00406-8

Palanikumar P, Daffni Benitta DJ, Lelin C et al (2018) Effect of Argemone mexicana active principles on inhibiting viral multiplication and stimulating immune system in Pacific white leg shrimp Litopenaeus vannamei against white spot syndrome virus. Fish Shellfish Immunol 75:243-252. https://doi.org/10.1016/j.fsi. 2018.02.011

Parveen S, Misra R, Sahoo SK (2012) Nanoparticles: a boon to drug delivery, therapeutics, diagnostics and imaging. Nanomedicine Nanotechnology, Biol Med 8:147-166. https://doi.org/10.1016/j. nano.2011.05.016

Perumal P, Sekar V, Rajesh V et al (2010) In vitro antioxidant activity of Argemone mexicana roots. Int J PharmTech Res 2:1477-1482

Pholdaeng K, Pongsamart S (2010) Studies on the immunomodulatory effect of polysaccharide gel extracted from Durio zibethinus in Penaeus monodon shrimp against Vibrio harveyi and WSSV. Fish Shellfish Immunol 28:555-561. https://doi.org/10.1016/j. fsi.2009.12.009

Pongsamart S, Nantawanit N, Lertchaiporn J, Lipipun V (2005) Novel water soluble antibacterial dressing of durian polysaccharide gel. Acta Hortic 678:65-73. https://doi.org/10.17660/ActaH ortic.2005.678.8

Pradeep B, Rai P, Mohan SA et al (2012) Biology, host range, pathogenesis and diagnosis of white spot syndrome virus. Indian $\mathrm{J}$ Virol 23:161-174. https://doi.org/10.1007/s13337-012-0079-y

Rajan PR, Ramasamy P, Purushothaman V, Brennan GP (2000) White spot baculovirus syndrome in the Indian shrimp Penaeus monodon and $P$. indicus. Aquaculture 184:31-44. https://doi.org/10. 1016/S0044-8486(99)00315-4

Rajashekar Reddy CB, Dinesh S, Anusha N et al (2016) Antiviral activity of 3-(1-chloropiperidin-4-yl)-6-fluoro benzisoxazole 2 against White spot syndrome virus in Freshwater crab, Paratelphusa hydrodomous. Aquac Res 47:2677-2681. https://doi.org/ 10.1111/are. 12704 
Rameshthangam P, Ramasamy P (2007) Antiviral activity of bis(2methylheptyl)phthalate isolated from Pongamia pinnata leaves against white spot syndrome virus of Penaeus monodon Fabricius. Virus Res 126:38-44. https://doi.org/10.1016/j.virusres. 2007.01.014

Rhodes G, Huys G, Swings J et al (2000) Distribution of oxytetracycline resistance plasmids between aeromonads in hospital and aquaculture environments: implication of Tn1721 in dissemination of the tetracycline resistance determinant Tet A. Appl Environ Microbiol 66:3883-3890. https://doi.org/10.1128/AEM. 66.9.3883-3890.2000

Rietschel ET, Kirikae T, Schade FU et al (1993) The chemical structure of bacterial endotoxin in relation to bioactivity. Immunobiology 187:169-190. https://doi.org/10.1016/S0171-2985(11)80338-4

Rogers JV, Parkinson CV, Choi YW et al (2008) A preliminary assessment of silver nanoparticle inhibition of monkeypox virus plaque formation. Nanoscale Res Lett 3:129-133. https://doi.org/10. 1007/s11671-008-9128-2

Romo-Quiñonez CR, Álvarez-Sánchez AR, Álvarez-Ruiz P et al (2020) Evaluation of a new Argovit as an antiviral agent included in feed to protect the shrimp Litopenaeus vannamei against white spot syndrome virus infection. PeerJ 2020:1-22. https://doi.org/ 10.7717/peerj.8446

Rungrassamee W, Maibunkaew S, Karoonuthaisiri N, Jiravanichpaisal P (2013) Application of bacterial lipopolysaccharide to improve survival of the black tiger shrimp after Vibrio harveyi exposure. Dev Comp Immunol 41:257-262. https://doi.org/10.1016/j.dci. 2013.05.021

Sahu D, Sharma S, Singla RK, Panda AK (2017) Antioxidant activity and protective effect of suramin against oxidative stress in collagen induced arthritis. Eur J Pharm Sci 101:125-139. https:// doi.org/10.1016/j.ejps.2017.02.013

Sakai M (1999) Current research status of fish immunostimulants. Aquaculture 172:63-92. https://doi.org/10.1016/S0044-8486(98) 00436-0

Salyers AA, Gupta A, Wang Y (2004) Human intestinal bacteria as reservoirs for antibiotic resistance genes. Trends Microbiol 12:412-416. https://doi.org/10.1016/j.tim.2004.07.004

Secombes CJ (1994) Enhancement of fish phagocyte activity. Fish Shellfish Immunol 4:421-436

Shen Q, Shao J, Peng Q et al (2010) Hydroxycoumarin derivatives: novel and potent $\alpha$-glucosidase inhibitors. J Med Chem 53:82528259. https://doi.org/10.1021/jm100757r

Singer AC, Xu Q, Keller VDJ (2019) Translating antibiotic prescribing into antibiotic resistance in the environment: a hazard characterisation case study. PLoS One 14. https://doi.org/10.1371/journal. pone. 0221568

Singh S, Singh TD, Singh VP, Pandey VB (2010) Quaternary alkaloids of Argemone mexicana. Pharm Biol 48:158-160. https://doi.org/ $10.3109 / 13880200903062622$

Siwicki AK, Anderson DP, Rumsey GL (1994) Dietary intake of immunostimulants by rainbow trout affects non-specific immunity and protection against furunculosis. Vet Immunol Immunopathol 41:125-139. https://doi.org/10.1016/0165-2427(94)90062-0

Song Y L, Hsieh YT (1994) Immunostimulation of tiger shrimp (Penaeus monodon) hemocytes for generation of microbicidal substances: analysis of reactive oxygen species. Dev Comp Immunol 18(3):201-209. https://doi. org/10.1016/0145-305x(94)90012-4

Söderhäll K, Cerenius L (1998) Role of the prophenoloxidase-activating system in invertebrate immunity. Current Opinion in Immunology 10(1):23-28. https://doi.org/10.1016/S0952-7915(98) 80026-5

Speshock JL, Murdock RC, Braydich-Stolle LK et al (2010) Interaction of silver nanoparticles with Tacaribe virus. J Nanobiotechnology 8:1-9. https://doi.org/10.1186/1477-3155-8-19
Stentiford GD, Bonami JR, Alday-Sanz V (2009) A critical review of susceptibility of crustaceans to taura syndrome, yellowhead disease and white spot disease and implications of inclusion of these diseases in European legislation. Aquaculture 291:1-17. https://doi.org/10.1016/j.aquaculture.2009.02.042

Sudheer NS, Philip R, Singh ISB (2011) In vivo screening of mangrove plants for anti WSSV activity in Penaeus monodon, and evaluation of Ceriops tagal as a potential source of antiviral molecules. Aquaculture 311:36-41. https://doi.org/10.1016/j.aquaculture. 2010.11.016

Sung HW, Liang IL, Chen CN et al (2001) Stability of a biological tissue fixed with a naturally occurring crosslinking agent (genipin). J Biomed Mater Res 55:538-546. https://doi.org/10.1002/10974636(20010615)55:4\%3c538::AID-JBM1047\%3e3.0.CO;2-2

Suphantharika M, Khunrae P, Thanardkit P, Verduyn C (2003) Preparation of spent brewer's yeast $\beta$-glucans with a potential application as an immunostimulant for black tiger shrimp, Penaeus monodon. Bioresour Technol 88:55-60. https://doi.org/10.1016/ S0960-8524(02)00257-2

Syed Musthaq S, Madhan S, Sahul Hameed AS, Kwang J (2009) Localization of VP28 on the baculovirus envelope and its immunogenicity against white spot syndrome virus in Penaeus monodon. Virology 391:315-324. https://doi.org/10.1016/j.virol.2009.06. 017

Thanardkit P, Khunrae P, Suphantharika M, Verduyn C (2002) Glucan from spent brewer's yeast: Preparation, analysis and use as a potential immunostimulant in shrimp feed. World J Microbiol Biotechnol 18:527-539. https://doi.org/10.1023/A:1016322227 535

Thilsted SH, Thorne-Lyman A, Webb P et al (2016) Sustaining healthy diets: the role of capture fisheries and aquaculture for improving nutrition in the post-2015 era. Food Policy 61:126-131. https:// doi.org/10.1016/j.foodpol.2016.02.005

Verbruggen B, Bickley LK, van Aerle R et al (2016) Molecular mechanisms of white spot syndrome virus infection and perspectives on treatments. Viruses 8:1-29. https://doi.org/10.3390/v8010023

Verma AK, Gupta S, Singh SP, Nagpure NS (2017) An update on mechanism of entry of white spot syndrome virus into shrimps. Fish Shellfish Immunol 67:141-146. https://doi.org/10.1016/j. fsi.2017.06.007

Wang XW, Wang JX (2013) Diversity and multiple functions of lectins in shrimp immunity. Dev Comp Immunol 39sa:27-38. https:// doi.org/10.1016/j.dci.2012.04.009

Wang J, Chen L, Liang Z et al (2017) Genipin inhibits LPS-induced inflammatory response in BV2 microglial cells. Neurochem Res 42:2769-2776. https://doi.org/10.1007/s11064-017-2289-6

Willett W, Rockström J, Loken B et al (2019) Food in the Anthropocene: the EAT-Lancet Commission on healthy diets from sustainable food systems. Lancet 393:447-492. https://doi.org/10. 1016/S0140-6736(18)31788-4

Xie Q, Liu Y, Luo F et al (2019) Antiviral activity of cathelicidin 5, a peptide from Alligator sinensis, against WSSV in caridean shrimp Exopalaemon modestus. Fish Shellfish Immunol 93:8289. https://doi.org/10.1016/j.fsi.2019.07.043

Yang W, Tran NT, Zhu CH et al (2021) Immune priming in shellfish: a review and an updating mechanistic insight focused on cellular and humoral responses. Aquaculture 530:735831. https://doi.org/ 10.1016/j.aquaculture.2020.735831

Yeh MS, Lai CY, Liu CH et al (2009) A second proPO present in white shrimp Litopenaeus vannamei and expression of the proPOs during a Vibrio alginolyticus injection, molt stage, and oral sodium alginate ingestion. Fish Shellfish Immunol 26:49-55. https://doi. org/10.1016/j.fsi.2008.10.003

Zhang Z, Gu L, Wang B et al (2019) Discovery of novel coumarin derivatives as potent and orally bioavailable BRD4 inhibitors 
based on scaffold hopping. J Enzyme Inhib Med Chem 34:808817. https://doi.org/10.1080/14756366.2019.1587417

Zhu F, Zhang X (2012) Protection of shrimp against white spot syndrome virus ( WSSV ) with $\beta$-1, 3- D -glucan-encapsulated vp28-siRNA Particles. 63-68. https://doi.org/10.1007/ s10126-011-9387-2
Publisher's note Springer Nature remains neutral with regard to jurisdictional claims in published maps and institutional affiliations. 